NBER WORKING PAPER SERIES

\title{
INTERNAL CAPITAL MARKETS IN TIMES OF CRISIS: THE BENEFIT OF GROUP AFFILIATION IN ITALY
}

\author{
Raffaele Santioni \\ Fabio Schiantarelli \\ Philip E. Strahan \\ Working Paper 23541 \\ http://www.nber.org/papers/w23541 \\ NATIONAL BUREAU OF ECONOMIC RESEARCH \\ 1050 Massachusetts Avenue \\ Cambridge, MA 02138 \\ June 2017
}

We would like to thank Giorgio Albareto, Rui Albuquerque, Riccardo De Bonis, Luigi Guiso, Fabiano Schivardi and participants to the Boston College Macro Lunch and to the Carroll School Finance Seminar for useful comments and suggestions. We are also grateful to Cerved for access to the Gruppi Italiani data set. The views expressed in this paper are those of the authors' alone and do not necessarily represent those of the institutions with which they are affiliated or the views of the National Bureau of Economic Research.

NBER working papers are circulated for discussion and comment purposes. They have not been peer-reviewed or been subject to the review by the NBER Board of Directors that accompanies official NBER publications.

(C) 2017 by Raffaele Santioni, Fabio Schiantarelli, and Philip E. Strahan. All rights reserved. Short sections of text, not to exceed two paragraphs, may be quoted without explicit permission provided that full credit, including $(\odot$ notice, is given to the source. 
Internal Capital Markets in Times of Crisis: The Benefit of Group Affiliation in Italy

Raffaele Santioni, Fabio Schiantarelli, and Philip E. Strahan

NBER Working Paper No. 23541

June 2017

JEL No. G01,G21,G3

\section{$\underline{\text { ABSTRACT }}$}

Italy's economic and banking systems have been under stress in the wake of the Global Financial Crisis and Euro Crisis. Firms in business groups have been more likely to survive this challenging environment, compared to unaffiliated firms. Better performance stems from access to an internal capital market, and the survival value of groups increases, inter alia, with groupwide cash flow. We show that actual internal capital transfers increase during the crisis, and these transfers move funds from cash-rich to cash-poor firms and also to those with more favorable investment opportunities. The ability to borrow externally provides additional funds that are shared across group affiliated firms. Our results highlight the benefits of internal capital markets when external capital markets are tight or distressed.

Raffaele Santioni

Bank of Italy

raffaele.santioni@bancaditalia.it

Fabio Schiantarelli

Department of Economics

Boston College

140 Commonwealth Avenue

Chestnut Hill, MA 02467

and IZA

schianta@bc.edu
Philip E. Strahan

Carroll School of Management

324B Fulton Hall

Boston College

Chestnut Hill, MA 02467

and NBER

philip.strahan@bc.edu 


\section{Introduction}

The Italian banking system began experiencing large credit losses starting at the beginning of the 2008 Global Financial Crisis and increasing further with the onset and deepening of the Euro Crisis in 2011. By December of 2015, aggregate bad loans had reached about $€ 200$ billion, or approximately 8\% of total loans outstanding (Figure 1). Losses are substantially higher when other troubled loans not yet written off are included. Unlike other recent banking problems, where losses were concentrated in real estate or sovereign debt exposure, most of these losses - close to $80 \%$ - come from bad debts in lending to non-financial businesses.

As a result of these banking system-wide losses, the availability of credit overall in Italy has been constrained. A number of recent studies find that credit supply by distressed banks was reduced in Italy during both the 2007-2008 Global Financial Crisis as well as the more recent Euro crisis (e.g., Albertazzi and Marchetti (2010); Bolton et al. (2013); Bofondi et al. (2013)). Losses at banks, combined with a weak legal system, have made the situation even worse because Italian firms sometimes delay payments to banks weakened by past losses and facing large time and legal expenses associated with enforcing loan defaults in court (Schiantarelli, Stacchini and Strahan (2016)). In addition, bank distress from exposure to risky sovereign debt has also reduced credit supply and helped propagate the Euro crisis from distressed to non-distressed countries across the Euro system (e.g. Popov and van Horen (2013); De Marco (2015)). This distress is one important reason for Italy's poor growth performance.

In this paper, we show that Italian business groups have helped firms survive the ongoing crisis by mitigating the costs of limited credit stemming from banking problems. 
In 2014, one-third of total employment in industry and services occurs at firms affiliated with Italian business groups (5.6 million employees). They produce over than $€ 376$ billion in value added, or 55 percent of total value added in industrial and service sectors. We test whether firms in these business groups use their access to the internal capital market as a substitute for external finance normally supplied by banks. We show that they do. Groups move capital from cash-rich to cash-poor firms, thereby benefiting firms that otherwise would face binding external financial constraints. Group affiliated firms also share financial resources obtained externally, but this mechanism weakens during the years of banking distress. Thus, sharing of internal cash resources supplants external finance during these years.

In our first set of tests, we show that affiliation with business groups helps firms survive the recent financial and economic downturn. Using the non-parametric KaplanMeier estimate of survival probabilities, we show that firms in large business groups are approximately 11 percentage points more likely to survive from 2006 to 2013, compared with unaffiliated firms (50\% survival probability for unaffiliated firms, versus $61 \%$ for firms in large groups). Firms in small groups are also more likely to survive, although the difference is smaller. To understand the role of internal capital markets, we report results that condition on firm fundamentals in a discrete-time logit hazard model with time-varying covariates. These models imply that the survival value of group affiliation becomes stronger during the crisis years. Moreover, controlling for fundamentals has only a small effect on the survival value of group affiliation, suggesting that such affiliation provides benefits beyond factors that might improve firm sales or firm profitability. Consistent with internal capital markets driving this difference, we show 
that survival increases not only when own fundamentals are stronger, but also when fundamentals of other group-affiliated fundamentals are stronger.

In our second set of results, we explore how access to the internal capital market enhances the survival value of group affiliation. We show that firms substitute toward the internal capital market when the banking system becomes distressed. Figure 2 shows this pattern at an aggregate level: intra-group capital transfers increase sharply as the Euro Crisis explodes in 2011, and this increase is mirrored by a drop in outside borrowing (mainly from banks.) Analysis of firm-level data supports this substitution. First, intra-group capital flows from firms with high cash flow to those with low cash flow and also toward firms with high investment opportunities (proxied by sales growth). ${ }^{1}$ Moreover, the marginal effect on transfers of negative shocks to a firm cash flow is greater for high sales firms. Second, after combining the firm-level data with data drawn from the Italian Central Credit Register, we are able to link the use of internal capital markets to the relative distress of a firm's own bank(s). In particular, we show that the internal capital flows are more pronounced among firms with more distressed banks. This is strong evidence that the internal capital substitutes in for the external markets when those markets are distressed.

Two conditions are required for internal capital markets to matter for investment and firm outcomes. First, external capital markets must be more costly than internal ones, otherwise Miller-Modigliani propositions would hold in the sense that firms would be able to exploit all positive net-present value (NPV) projects. Second, there must be some variation in the availability of cash resources relative to investment opportunities

${ }^{1}$ GDP does not change much during the first three quarters of 2008 and it starts declining substantially only in the fourth quarter of 2008. See Figure 1. 
across firms within the internal capital market. If all firms have excess cash, for example, then all would be able to finance their own projects internally; that is, without the need for internal (or external) capital. Similarly, if all firms within the internal capital market face cash shortages relative to investment options, then there would be little scope for reallocation across affiliated firms.

We develop our tests with these two conditions in mind. We need to measure the degree of constraints from both the external and the internal capital markets. For the former, identification comes from the shocks to the banking system starting in 2008 and worsening over the subsequent years; these shocks made bank credit less available and more expensive. ${ }^{2}$ We then improve the granularity of each firm's exposure to external financing constraints by conditioning on the health of their own set of bank lenders. For the latter, we measure sales growth as a proxy for each firm's investment opportunities and free cash flow as a measure of each firm's scope for internal capital transfers within the internal capital market. Our data are sufficiently rich to allow us to control for potentially confounding effects (such as variation in unobserved aspects of investment opportunities) with granular fixed effects. In some specifications, we even control for both firm, industry $\mathrm{x}$ time, region $\mathrm{x}$ time, and group $\mathrm{x}$ time effects. Our main results are stable across a host of permutations of sets of these fixed effects.

The existing literature has not achieved consensus about the value of internal capital markets. The theoretical literature has identified tradeoffs associated with internal capital market use, relative to the external markets. On one hand, models such as Stein (1997) emphasize that with external financial constraints, firms use internal capital

\footnotetext{
${ }^{2}$ Interest rates on loans start decreasing from 2014 onward, but credit supply remains tight until the end of 2015.
} 
transfers to move funds away from low-return projects and toward high-return ones. Consistent with our results, that paper suggests more movements of capital across affiliated firms with different investment opportunities during times when external capital is especially expensive or hard to access. Other papers, however, have focused on offsetting agency costs (e.g. divisional rent seeking) of internal capital markets in large, diversified conglomerates (see, e.g., Lang and Stulz (1994); Scharfstein and Stein (2000)). Subsequent empirical studies raise doubts about whether a large and welldiversified internal capital market creates or destroys value (e.g., Whited, 2001; Schoar, 2002; Villalonga, 2004). ${ }^{3}$

Our paper suggests that during periods when external capital markets are constrained, the internal capital market likely increases firm value, as its use increases and firms with access to large internal capital markets are more likely to survive the crisis. ${ }^{4}$ This result is consistent with Kuppuswamy and Villalonga (2015), who find that U.S. diversified conglomerates became significantly more valuable than otherwisesimilar single segment firms during the 2008 financial crisis. In addition, Matvos and Seru (2014) report simulations based on the 2008 financial crisis which suggest diversified conglomerates are more likely to share resources across the internal capital market when external finance is costly. And, in a related study, Matvos, Seru and Silva (2016) offer evidence that diversifying mergers are more likely during periods in which external market constraints are more likely to bind.

\footnotetext{
${ }^{3}$ Consistent with internal capital markets reducing firm value, Lamont (1997) provides evidence that oil company investment in non-oil segments represented over-investing in low profit projects.

${ }^{4}$ We do not explore valuation effects because almost all of our firms do not have publicly traded equity.
} 
Our results also provide some evidence that internal capital markets do involve a tradeoff between agency costs versus their ability to move capital to better uses. Large groups consistently move capital toward higher sales-growth firms, regardless of conditions in the external capital market. But among firms affiliated with small groups, where agency problems may be more likely to be relevant, we find no correlation between intra-group capital reallocation and sales growth during the non-crisis years. ${ }^{5}$ During the crisis, however, both large and small groups move capital across their affiliates similarly - away from low-growth and toward higher growth firms.

Our study also supports earlier papers that find evidence that investment rates are insulated from cash-flow shocks for firms with access to a wide internal capital market. Schiantarelli and Sembenelli (2000), also studying Italian business groups, find that investment is less sensitive to cash flow for firms owned by large business groups. Similarly, Shin and Stulz (1998) find lower investment-cash flow sensitivities for U.S. segments held by diversified conglomerates. Both of these studies are consistent with our finding that there is an active internal capital market within business groups, but they suffer from the well-known ambiguities that emerge in interpreting investment links to cash flow (e.g., Alti (2003)). ${ }^{6}$ Because we study the actual movements of capital, rather than investment itself, our approach does not suffer from these criticisms.

Our paper extends a small number of studies that test how business groups circulate their internal capital market cash flow across affiliated firms. Gopalan et al.

\footnotetext{
${ }^{5}$ Small groups are more likely to have family control and management, which has been associated with greater agency problems (e.g., Bennedsen et al., 2007).

${ }^{6}$ Shin and Stulz also show that the sensitivity to cash flow does not depend upon investment opportunities, measured by ' $\mathrm{q}$ ' of the segment a firm in a conglomerate belongs to. This result leads them to question whether funds are efficiently allocated within a conglomerate.
} 
(2007) exploit business groups in India and, like us, find that intra-group capital transfers are used to help affiliated firms who are facing low cash flow, but their study does not consider how the value of the internal capital market responds to shocks to the external providers of capital, as we do. Unlike the earlier literature, our data allow us to measure all sources of capital deployed by a given firm from group-affiliated firms, including financial debt, trade credit and equity. Almeida et al. (2015) study how Korean Chaebolrelated firms move equity within their groups, but do not capture the full extent of the internal capital market, as they focus only on investment opportunities but not cash flow, which we find to be the most important variable driving intra-group transfers. Their study also relies on a much smaller data set which does not allow them to address potentially confounds with granular fixed effects of various types, as we do.

The next section provides a brief overview of the role of business groups in Italy. Section III then describes our data, while Section IV discusses our empirical methodology and results. Section V concludes.

\section{Business Groups in Italy}

Business groups remain a prevalent organizational form around the world, across both developed and developing economies (e.g., La Porta et al. (1999); Khanna, (2000)). Business groups are widely diffuse in Italy, and group affiliation appears to be a persistent feature within the domestic corporate landscape (e.g., Cannari and Gola (1996); Bianchi et al. (2005); Bianchi et al. (2008)). According to the Italian Civil Code, a business group exists when a dominant influence on a firm is exerted through centralized coordination. Such coordination may occur when control is performed on either a de jure 
or a de facto basis, or when a firm's capital is equally distributed among different owners, or when corporate decisions are subject to any shareholders agreements.

Traditionally, a few key families and government entities played the central role in shaping the ownership structure of major Italian business groups. Such families have dominated the domestic corporate scene since the 1950s, initially benefiting from the supportive role of the state and, later, from a revival of the stock market. The state's role - as well as the role of once-dominant families - has gradually decreased in the governance structure of national groups, especially after the wave of privatization starting in the 1990s. Indeed, after this phase, an internationalization process occurred during which foreign groups increased their presence in Italy, especially in the large retail sector and in telecommunications. Domestic groups also expanded their ownership structure abroad, particularly in those countries that were experiencing fast economic development (Santioni (2011)).

Business groups play a prominent economic role in Italy. In 2014, with 5.6 million employees, they represent about one-third of total employment in the industrial and service sectors, and they produce about 55 percent of total value added. Most groups have a fairly simple structure, with just one or two active firms based in Italy. Other large groups have a more complex ownership structure, often with more than ten domestic firms. These large groups are fewer in number but have a stronger economic impact. Many small groups are likely to be family dominated, with less structured professional management and governance, and a higher weight given to the nonpecuniary benefits from control. 
The historical memory of bank failures in the 1920s and 30s, along with bank reforms of 1936, generated a system in Italy with separation between banking and industry, and between short-term and long-term lending institutions. While the latter distinction disappeared in the 1990s, the separation between ownership of industry and ownership of financial institutions still characterizes the Italian economy. For instance, the 1993 banking law stipulates that entities with relevant industrial interests cannot control more than $15 \%$ of voting shares of a banking institution. Moreover, banks are restricted in their shareholding of non-financial firms to a maximum of $15 \%$ of bank capital overall, and just 3\% for shares in a single firm. Although some of these limits were relaxed in 2008, there are no significant cross-ownership relationships between banks and firms. ${ }^{7}$ Thus, business groups do not have special access to bank credit, as in structures like the Japanese Keiretsu. Yet being a group member is likely to confer an advantage in accessing external finance (Schiantarelli and Sembenelli (2000)). ${ }^{8}$

\section{Data and Descriptive Statistics}

We build a novel dataset that combines the structure of Italian groups with data on both firm performance and measures of the health of their bank (or banks). In this section we describe the data sources and present some basic descriptive statistics.

\section{III.i. Data}

\footnotetext{
7 The separation between banking and commerce in Italy is similar to the one that characterizes the US.

${ }^{8}$ On the real consequences of credit supply shocks in Italy see Cingano, Manaresi and Sette (2016) and Balduzzi, Brancati, and Schiantarelli (2016).
} 
To build our data, we combine several sources. We rely on the Gruppi Italiani data (produced by Cerved) for information on the ownership structures of the entire universe of Italian groups (both financial and non-financial). We obtain the firm-level balance sheet, income statement and statement of cash flows information from the Centrale dei Bilanci data set (also from Cerved). We match these with firm-level individual loan data from the Italian Credit Register and bank-level data from the Bank of Italy Supervisory Reports to construct a firm-specific measure of the quality the bank (or banks') portfolio from which each firm borrows.

We focus our analysis of intra-group capital transfers between firms affiliated with large and small domestic business groups, as transfer to firms outside of Italy relevant for Italian firms associated with foreign groups or holding companies - are not observable in our data. While the definition of a large versus small group is a bit arbitrary, we use a cutoff of 50 employees and no more than 10 million euros in sales or total asset to draw a distinction between groups likely to be controlled by a family versus large ones that are more likely to have a formal group structure and professional management. This categorization, we admit, is imperfect, so we report all of our results both with and without this separation of the sample. Moreover, we want to avoid linking the group-size definition to ex post success of firms owned by a given group type. Hence, we define each group based on its size in the first year in which it enters the sample, and then we leave the definition constant across all subsequent time periods. Thus, we would keep a group that starts with, say, 60 employees but shrinks to 45 due to poor performance in the large-group category. 
Although ours is the first study able to combine the comprehensive financial statement data to time-varying measure of ownership structure, we are restricted in our access to just three points in time: 2006, 2010 and $2014 .^{9}$ In other words, we can only merge the ownership connections to the year-by-year financial statements during these three points in time. In our regression analysis, which we describe in more detail below, we focus on annual panel data from 2004 to 2014. Hence, we need to assume that ownership connections remain constant over periods longer than a single year. To minimize classification error, we assign ownership as follows: we use the 2006 ownership data for all firms during the years 2004-2007; the 2010 ownership information we assign to the years 2008-2011; and the 2014 ownership data we assign to the years 2012-2014. Our strategy works well because business group affiliation in Italy is persistent over time.

After combining Cerved with the structural data from Gruppi Italiani, we apply several filters to remove data that may be unreliable. First, we drop observations with zero total assets or zero sales. Second, we include firms with financial statements reported in abbreviated form, under the condition that financial or trade aggregates in the balance sheet are recognized and fully disclosed. Third, we require the disclosure of the full statement of cash flow. And fourth, we drop financial companies.

According to national rules, firms are required to indicate their lending or borrowing positions within the group on their balance sheets (article 2424 of the Italian Civil Code). We use this information to construct Intra-Group Net Financial Position/Assets, which equals the total amount of financial debt owed by a given firm to

${ }^{9}$ Santioni and Supino (2017) take a first step in this direction using ownership data for 2006 and 2014. This paper contains a descriptive analysis of Italian groups and of the working of their internal capital markets when credit becomes tight. 
all other firms affiliated with the same group, net of loans provided, as a percentage of the firm's total assets. The variable represents non-arm's length, net debt that, we argue, provides the main tool used by groups to effect intra-group transfers of capital. Positive values of Intra-Group Net Financial Position/Assets indicate that a firm is borrowing (that is, demanding funds) from the internal capital market; negative values indicate that the firm is lending (i.e., supplying funds) to the internal capital market. Hence, across all firms in a given group, the variable averages to zero (appropriately weighted). We also construct a second measure of intra-group transfers - the Intra-Group Net Position (total)/Assets - that includes net trade debt as well as financial debt. Trade debt (Gross) is less important quantitatively than financial debt, representing around $35 \%$ of gross intragroup financial debt - the latter of which equals about $30 \%$ of total financial debt. We do not include equity transfers because in the Italian context they are not a significant method to transferring resources between group members. Disclosure on the details on intragroup transactions, however, are not compulsory for those firms that prepare abridged financial statements, so we drop those firms that do not report this item.

Finally, we use the Credit Register loan data and the bank balance sheet information from the Bank of Italy Supervisory Reports to construct our firm specific measure of the health of each firm's bank(s). Italy's Credit Register is an archive providing lender-borrower level data on characteristics of loans extended by banks operating in Italy. The data include information on loan type (credit lines, term loans), size, maturity, the pledging of real collateral, personal guarantees, accounts receivable, and ex post performance. From 2009 on, loans are reported when tranches exceed $€ 30,000$ by the entire population of credit institutions, having been lowered from $€ 75,000$ 
before 2009. These data allow us to measure those banks from which each firm has borrowed significant funds, which we in turn use to assess the average heath of each firm's banks. As such, we construct the variable Bad Loans, equal to the weighted average of the banks' ratio of bad loans to total assets, where the weights equal the fraction of credit received by a given firm from each of its banks. This approach allows us to exploit both the time series and cross sectional variation in a firm's credit access. As shown in Figure 3, Bad Loans has substantial variation both over time, rising on average in the post-crisis years, and displaying an increased dispersion across firms.

\section{III.ii. Summary Statistics}

Table 1 reports summary statistics for large-group and small-group affiliated firms, as well as for unaffiliated firms, with these data broken into non-crisis (2004-2008) and crisis (2009-2014) years. Clearly the small-group and unaffiliated firms are more similar to each other in terms of size, than either type is relative to large-group affiliated firms. For small-groups, the median firm has just $€ 908,000$ in assets, compared to $€ 417,000$ for unaffiliated firms (non-crisis years); these are clearly very small firms on average. (And, by construction the small-group affiliated firms start in the sample with fewer than 50 employees.) In contrast, firms associated with large groups are themselves much larger - at the median these firms have €5.9 million in assets (pre-crisis). All three types experienced large declines in operating performance from the non-crisis to the crisis years, with sales growth falling across the whole distribution.

For the group-affiliated firms, Table 1 also shows how Intra-Group Net Financial Position/Assets varies across firms and over time. As expected, the median value is near 
zero, which follows from the fact that the measure nets up to zero within each group. The aggregate growth in gross intra-group financial borrowing shows a sharp increase in internal capital transfers in 2011, the year that the Euro crisis reached its nadir (recall Figure 2). As the figure also shows, lending from external source shrinks sharply in 2011 as well and the contraction continues into $2014 .{ }^{10}$ These aggregate patterns suggest substitution from the external to internal sources of financing, although these overall growth rates are also affected by the overall economic conditions (i.e., by demand for capital). But the patterns clearly show an overall rise in the importance of the internal capital market relative to the external financial markets during the crisis years.

Table 2 reports transition probabilities for our firms over two, non-overlapping periods: 2006 to 2010 and 2010 to 2014. Recall that these two periods (or, three points in time) represent the only ones in which we have exact data allowing observation of firm ownership. The transition matrix shows, first, that firms normally either remain in the same category or they exit the sample. This general pattern holds in both periods. Second, the rate of exit increases across all categories in the second period, which represents most of the crisis years. Third, the increase in exit rates is higher for unaffiliated and small-group affiliated firms than for firms affiliated with large groups. For example, unaffiliated firms' exit rates increase from $32.3 \%$ to $39.8 \%$, an increase of 23\%. Small group affiliated firms' exit rates increase from $31.2 \%$ to $38 \%$, as increase of 22\%. In contrast, large-group affiliated firms' exit rates increase much less, rising from $25.5 \%$ to $28.9 \%$ (or $13 \%$ ). Although exit from the sample does not necessarily imply the death of a firm, these simple comparisons suggest that affiliation with a large group may

\footnotetext{
${ }^{10}$ The figure is constructed from continuing firms. Hence it does not reflect entry or exit of firms.
} 
enhances the likelihood that a firm will survive the poor economy and associated reductions in bank credit that have plagued Italy in recent years. We will make more precise what we mean by a firm "failing" and discuss the issue of firm survival more formally in the next section.

\section{Empirical Methods and Results}

We now provide evidence on the importance of group membership before the financial crisis and in the years that followed. These years include the sovereign debt crisis and a steady deterioration of the health of Italian banks due to the accumulation of bad loans on bank portfolios. The latter, in turn, reflected the poor overall performance of the Italian economy. We first present an analysis of firm survival, comparing groupaffiliated and non-affiliated firms. We then investigate the determinants of intra-group capital flows, focusing specifically on how these flows differ in the pre-crisis versus crisis years, and how the health of the banking sector affects them.

\section{IV.i Discrete-time hazard Analysis}

Is group affiliation beneficial to firms? If so, is it particularly important during crisis? To answer these questions, we test whether group affiliation raises firm survival probabilities, using a discrete-time proportional hazard model with time-varying covariates (Allison (1982) and Singer and Willett (1993)). The model defines the hazard probability for a given firm $i$ over discrete time intervals (=one year in our context), as follows: 


$$
\mathrm{P}_{\mathrm{it}}=\operatorname{Prob}\left(\mathrm{T}_{\mathrm{i}}=\mathrm{t} \mid \mathrm{T}_{\mathrm{i}}>=\mathrm{t}, \mathrm{X}_{\mathrm{it}}\right)
$$

where $\mathrm{P}_{\mathrm{it}}$ represents the probability that firm $i$ fails in period $t$, conditional on having survived until the beginning of the interval. This probability depends on a set of timevarying, firm-specific variables $\left(\mathrm{X}_{\mathrm{it}}\right)$. So, for example, the hazard rate for 2011 would be equal to the probability that the firm fails during the year 2011, conditional on its having survived to the beginning of that year and conditional on its covariates at the beginning of that year. Because time is measured in discrete intervals (years), these hazard rates are proper probabilities and we model them using a standard logistic function. One major advantage of this approach is that time-varying covariates can be introduced and their coefficients estimated easily. With this formulation, the logistic function of the hazard probability depends on time indicators and firm-specific, time-varying covariates, as follows:

$$
\mathrm{P}_{\mathrm{it}}=1 /\left[1+\exp \left(\mathrm{X}_{\mathrm{i}, \mathrm{t}} \beta-\alpha_{\mathrm{t}}\right)\right]
$$

The equation becomes linear when rewritten in the log odds ratio form:

$$
\operatorname{Ln}\left(\mathrm{P}_{\mathrm{i}, \mathrm{t}} /\left(1-\mathrm{P}_{\mathrm{i}, \mathrm{t}}\right)\right)=\mathrm{X}_{\mathrm{i}, \mathrm{t}} \beta+\alpha_{\mathrm{t}}
$$

where $X_{i, t}$ is the vector of k-covariates, $\beta$ the associated vector of coefficients and $\alpha_{t}$ year indicator variables that we will allow also to vary by firm type.

Since we want to draw inferences about the utility of the internal capital market (i.e., the role of capital transfers), we need to control for the economic environment, the set of cost conditions and the state of demand conditions facing firms, as these will all have a large effect on survival but might be correlated with group affiliation. In addition, 
we need to account for firm size, as larger firms likely can absorb larger negative shocks without failing compared to smaller firms. Similarly older firms may be less informationally opaque than younger firms, more able to access external finance, and, therefore, may have a higher probability of survival. ${ }^{11}$ Given these controls, we then argue that any residual effect of group status on survival reflects advantages of the internal capital market. Since all firms in Italy experience, to put it kindly, a challenging economic downturn, this test should be quite powerful.

The cost of the logit model is that we need to make a specific assumption about the shape of the hazard probability function, but by doing so we can estimate models with substantial heterogeneity related to location, industry, and time varying firm characteristics. As a preliminary exercise that avoids making parametric assumptions, we also report below further evidence on survival rates by plotting the Kaplan-Meier estimate of the survival function and hazard rates over time for various types of firms. We parameterize the covariates in the logit hazard model, as follows:

$$
\begin{aligned}
& \mathrm{X}_{\mathrm{i}, t} \beta=\beta_{1} \text { Group }_{i}+\beta_{2} \text { Group }_{i} \times \text { Crisis }_{t}+\beta_{3} \text { Sales Growth }_{i, t-1}+ \\
& \beta_{4} \text { Cash flow }_{i, t-1} / \text { Assets }_{i, t-2}+\beta_{5} \log \text { age }_{i}+\text { Year, Size, Province and Industry } \\
& \text { Indicators. }
\end{aligned}
$$

In some specifications, the year effects vary by industry, province and size. In Equation (1), the coefficients of interest are $\beta_{1}$ and $\beta_{2}$, as they test whether group affiliated firms have higher (or lower) failure rates relative to unaffiliated firms before and after the crisis. The unaffiliated firms provide the comparison sample for the group-

${ }^{11}$ Firm age may also proxy for hard-to-observe variables such as managerial risk aversion, which likely affect failure rates. Note that our results linking failure rates to group states are not sensitive to whether or not we control for age. 
affiliated firms. We include only those firms that exist as of 2006, but we allow variables that capture fundamental shocks - sales growth and cash flow - to change each year, from 2006 to 2013. Group affiliation is allowed to change, while size and age are left at their 2006 values. We also estimate models that separate the effect of group status based on group size, as the aggregate data in Table 1 suggest that large group-affiliated firms were more likely to survive during the crisis years.

Equation (1) 'controls' for the general economic environment with the year indicators. As such, we do not need to control for the direct effect of the Crisis indicator in Equation (1). To control for specific shocks faced by firms, we control for lagged values of both Sales Growth and Cash Flow, in addition to log age. ${ }^{12}$ In the hazard model, however, large sets of fixed effects cannot be absorbed, as they can in linear models. Instead, we parameterize and estimate the effects of indicator variables to account for industry, region and size differences. Variation in the overall macroeconomic environment is captured by the time-varying baseline hazard rate $\left(\alpha_{t}\right)$. And, in some models, we interact time with industry, region, and size effects.

Our sample includes those firms that were present in the sample in 2006. Later entrants are not considered. Moreover, we classify a firm as "failed" when it disappears permanently from the sample. In some (few) cases, we miss the firm balance sheet for one year, or even more, but then the firm reappears in the sample. In these cases we delete the entire string of information for that firm. In the same spirit, we end our survival analysis in 2013 and classify as failed in that year only firms that do not have a balance sheet both in 2013 and 2014.

\footnotetext{
${ }^{12}$ We draw the distinction between own v. other cash flow and sales growth later in the analysis, when we analyze the effects of group affiliation.
} 
The results for the Kaplan-Meier estimate of the survival function are reported in Figure 4, while the estimates of the discrete-time hazard are contained in Table 3. The simple results from the Kaplan-Meier analysis - which are no more than the raw survival and hazard rates themselves - suggest that the survival of a large-group affiliated firm is greater than that of both members of small groups or unaffiliated firms. For instance, the probability that a firm belonging to a large group survives from 2006 until 2013 is 61 percent, while it is approximately 53 percent for the member of a small group and 50 percent for unaffiliated firms. These estimates, however, do not control for firm level differences in growth opportunities or internal cash flow or for the industrial regional or size characteristics (time invariant or time varying). As a result one cannot attribute the differences in survival to a pure group effect, operating, for instance, through intra-group transfers.

To address fundamentals, Table 3 (Panel A) presents four specifications in which we allow the difference between unaffiliated and group members to vary between the pre- and post-crisis period. In column 1, we control (in addition to log age) for a common year effect and for industry, location and size effects. We allow for 25 industries, 20 regions and two firm-size categories (small firms have fewer than 50 employees and sales or asset less than $€ 10$ million, with others classified as large). In column 2, we introduce a firm's own cash flow and own sales growth as additional regressors. In column 3 and 4, we replicate these two specifications, but allow the year effects to interact with industry, region and size. In Panel B of Table 3, we then allow the group effects to differ between small versus large groups. 
Recalling that a negative coefficient on a variable means that it lowers the probability of failing, we see that unaffiliated firms fail at greater rates than group members in the pre-crisis period, and this difference becomes statistically significantly larger during the crisis period. In terms of magnitude, the odds ratio $\left(\mathrm{P}_{\mathrm{i}, \mathrm{t}} \mathrm{t}\left(1-\mathrm{P}_{\mathrm{i}, \mathrm{t}}\right)\right)$ of failing in the crisis years for a group member firm equals $77 \%$ of an independent firm, keeping constant the other firm characteristics (= exp(-0.26), using column 4 of Table 3 , Panel A). The effect of cash flow, sales growth and age enter the model as expected, with older firms, firms with greater sales growth or with greater cash flow less likely to fail. While the coefficient on cash flow is roughly 10 times as large as that the coefficient on sales growth, its standard deviation is roughly $1 / 10$; hence, their economic magnitudes are roughly equivalent. Also, adding sales growth and cash flow decreases somewhat the quantitative impact of group affiliation, but not by much and the effect remains highly significant. Thus, group affiliation's positive effect on firm survival does not appear to be mainly due to better fundamentals. Rather - as we show below - the differential survival reflects access to the internal capital market.

Table 3, Panel B augments the model to allow differences related to both firm size and group size. We do this in a simple way by constructing a set of mutually exclusive and exhaustive indicator variables, as follows: Large Independent = 1 for large, independent firms; Small Firm in Small Group = 1 for small firms in small groups; Small Firms in Large Group = 1 for small firms in large groups; and Large Firms in Large Group = 1 for large firms in large groups. Since small groups contain only small firms, these indicator variables exhaust all configurations. Small independent firms serve as the 
omitted category. We also allow the effect of each firm-group-type indicator to vary between the pre-crisis and crisis years.

The coefficients suggest a sensible ordering of firm failure rates: small, independent firms (the omitted category) are generally most likely to fail, as the coefficients on all but one of the coefficients on the firm-group-type indicators sign negatively. (The only exception: small firms in large groups during the pre-crisis years, which fail at rates similar to unaffiliated, small firms.) Small firms affiliated with either group type are next most likely to fail, followed by large independent firms, with large firms affiliated with large groups being the least likely to fail. Hence, controlling for firm size, group affiliation raises survival rates. The magnitudes suggest that large-group affiliation has a much larger effect than small-group affiliation, and the difference in these coefficients is statistically significant at any level of confidence. Moreover, the value of group affiliation for survival increases during the crisis years for both small and large firms, consistent with the more parsimonious specification in Panel A.

To understand magnitudes, consider the effect of group affiliation on large-firm failure, which can be inferred from the difference in the coefficients on Large Independent v. Large Firms in Groups. In the pre-crisis years, group affiliation lowers the odds ratio of failure for large affiliated firms by 0.07 , relative to the large unaffiliated ones, based on the coefficients from column $4(=\exp (-0.85)-\exp (-0.69))$. During the crisis years, the advantage of group affiliation increases, with the odds ratio of failure being 0.34 lower for group-affiliated, large firms (= $\exp (-0.96)$ - $\exp (-0.32))$.

Why do group-affiliated firms survive more than independent firms, especially during the crisis years? Our specifications in Table 3 control for firm fundamentals, yet 
the magnitude of group affiliation changes little when we leave these controls out. Thus, some mechanism other than a firm's own access to cash flow or investment opportunities must explain the benefits of group affiliation. To test whether access to the internal capital market at the group level helps firms, we estimate survival models for the groupaffiliated firms only, and test whether cash resource at other group-affiliated firms reduces this firm's failure rate. In particular, we modify equation (1) as follows:

$$
\begin{aligned}
& \mathrm{X}_{\mathrm{i}, \mathrm{t}} \beta=\beta_{1} \text { Sales } \text { Growth }_{i, t-1}+\beta_{2} \text { Other-Sales Growth }{ }_{i, t-1} \\
& +\beta_{3} \text { Cash flow }_{i,-1-1} / \text { Assets }_{i,-2} \beta_{4} \text { Other-Cash flow } \text { flt-1-1/Assets }_{i, t-2} \\
& +\beta_{5} \text { Crisis }_{t} \times \text { Sales Growth }{ }_{i, t-1}+\beta_{6} \text { Crisis }_{t} \times \text { Other-Sales Growth }{ }_{i, t-1} \\
& +\beta_{7} \text { Crisis }_{t} \times \text { Cash flow }_{i, t-1} / \text { Assets }_{i,-2-2}+\beta_{8} \text { Crisis }_{t} \times \text { Other-Cash flow } \text { flt-1-1 }_{\text {Assets }}{ }_{i,-2} \\
& +\beta_{9} \log \text { age }_{i,}+\beta_{10} \log (\text { asset ratio })_{i, t-1}+\text { Year, Size, Province and Industry } \\
& \text { Indicators. }
\end{aligned}
$$

In equation (2), we condition on the average sales growth and average cash flow of the other members of the firm's group (Other-Sales Growth and Other-Cash flow/Assets). In addition, we add a measure of the asset size of the firm relative to the sum of assets across all firms in its group (log(asset ratio)). As such, these models include only group-affiliated firms.

Table 4 reports the results. Coefficients are separated into two blocks of rows, with the first block reporting the effects of the firm's own fundamentals and the second reporting the effect of the fundamentals of other group-affiliated firms. As expected, a firm's own sales and cash flow shocks continue to affect failure rates very strongly (and with similar magnitudes to the models in Table 3). In addition, shocks to other firms affiliated with the group also have a statistically significant effect on this firm's failure. 
Thus, the potential to share resources across the group's internal capital market is associated with lower failure. When other group-affiliated firms have high sales and/or substantial cash flow, this firm is less likely to fail. The magnitudes are substantially smaller than that of own sales and cash flow, which makes sense because the firm's own fundamentals affect not only its access to funds, but also correlate with the firm's profitability and future business opportunities. In addition, the effect of shocks to both other sales growth and other cash flow increase in magnitude during the crisis years.

\section{IV.ii Intra-group Capital Transfers}

Together, the results of Tables 3 and 4 suggest that group affiliation helps firms survive by increasing their potential tor share funds across the group. Do firms actually share financial resources? To answer this question, we analyze capital transfers across group-affiliated firms. If internal capital markets explain group survival value, then financial resource sharing ought to be more pronounced when external markets become distressed. Hence, we first compare internal capital market transfers before versus after the onset of crisis. Then, we construct a measure of constraints from the external markets more precisely by exploiting firm-year variation in the health of a given firm's banks in a given year.

\section{Crisis versus Non-Crisis Years}

To provide tests over time, we regress capital transfers on investment opportunities and cash flow - both own and other - allowing these relationships to shift over time. Investment opportunities measure a firm's demand for financial resources, 
while cash flow measures a firm's supply of internal financial resources. If the firm's relative demand exceeds its internal supply of cash, then it would need to fill a financing gap either through a within-group transfer or by accessing the external market.

Given this conceptual framework, we report our baseline regression strategies, as follows:

Net Transfer ${ }_{i, t}=\beta_{1}$ Sales Growth $_{i, t}+\beta_{2}$ Other-Sales Growth ${ }_{i, t}$

$+\beta_{3}$ Cash $_{\text {flow }} /$ Assets $_{i, t-1}+\beta_{4}$ Other-Cash flow/Assets $i, t-1$

$+\beta_{5}$ Crisis,$t_{1} \times$ Sales Growth ${ }_{i, t}+\beta_{6}$ Crisis $_{t} \times$ Other-Sales Growth ${ }_{i, t}$

$+\beta_{7}$ Crisis $_{t} \times$ Cash flow $_{i, t} /$ Assets $_{i, t-1}+\beta_{8}$ Crisis $_{t} \times$ Other-Cash flow $_{i, t} /$ Assets $_{i, t-1}$

+ Fixed Effects $+\varepsilon_{i, t}$,

where $i$ represents the firm and $t$ the year. We report the two measures for Net Transfer ${ }_{i, t}$ described in Section III.i: the first includes intra-group net financial borrowing scaled by the end of previous period assets (we call this the Intra-Group Financial Position); the second adds the intragroup net trade position (accounts payable minus accounts receivable) to the intra-group net financial position in the numerator (we call this the Intra-Group Financial and Trade Position). To capture investment opportunities, we again use real sales growth. In some models we also allow coefficients to vary based on the type of business group (large or small).

The sample includes only group affiliated firms, as only these firms have access to an internal capital market. We capture unobserved heterogeneity by including a series of granular fixed effects: industry x year, province x year, and firm. We allow for 286 industrial sectors and 105 provinces, which generates much more detailed year effects in our linear regression for intragroup transfers than in the non-linear survival models. In 
some specifications, we also add a group-specific year effects. Finally, when we allow the slope coefficients to differ between small and large groups, we also permit the industry and location specific year effects to differ according to group size. By including so many fixed effects, we are able to remove potential sources of bias related to economic conditions at the industry and geographical levels. Since we allow these effects to vary with time, they will account for the rapid deterioration in the Italian economy during our sample period (recall Figure 1). To construct standard errors, we double cluster by firm and by group-year. ${ }^{13}$

Equation (3) explicitly models the idea that relative demand for and supply of funds is what motivates capital transfers. Other-Sales Growth captures the demand for funds elsewhere in the group (i.e., in the internal capital markets), defined as in the survival analysis. Other-Cash flow captures the availability of funds elsewhere in the group, and is also defined as in the survival analysis. Conversely, Sales Growth captures the effects of a firm's own demand for funds and Cash Flow captures its own supply of funds. We normalize each of the cash flow measures by the firm's assets at the end of the previous period; since the outcome is normalized with the same denominator, the coefficients have a natural interpretation as the marginal effect of an additional unit of cash flow on intra-firm transfers. In the most general specification, we incorporate group $\mathrm{x}$ year fixed effects. This empirical strategy, by differencing out the group-time means, is equivalent to re-defining the effects of investment opportunities and cash resources in a relative sense within a given group in a given year.

${ }^{13}$ Fixed effects help allay concern about omitted variables but not reverse causality. For example, perhaps receiving more capital transfers allows firms to experience higher cash flow or sales. This source of endogeneity cannot explain why cash flow effects would become so much greater during the crisis. Nevertheless, we have also estimated the regressions of Table 5 after lagging both cash flow and sales growth one year. These results are similar to those presented in Table 5. 
Panel A of Table 5 reports the estimates for equation (3). We report each regression first for Intra-Group Net Financial Position /Assets $_{t-1}$ (columns 1 and 2), and then for Intra-Group Net Financial and Trade Position ${ }_{t}$ Assets $_{t-1}$ (columns 3 and 4). ${ }^{14}$ Panel B allows the slope coefficients to differ between small groups and large ones. (The group-type indicators are absorbed by fixed effects.) Positive coefficients indicate that an increase in the explanatory variable leads a firm to use more funds from the internal capital market, whereas negative coefficients mean that an increase in the explanatory variable leads the firm to supply more funds to the internal capital market.

Both Panels A and B suggest that group-affiliated firms make greater use of capital transfers during the crisis years, particularly with regard to the effects of cash flow on transfers. Sales growth positively affects transfers in both periods, meaning that groups move capital efficiently - toward high sales growth firms. For example, the coefficient on Sales Growth is positive and significant in both crisis and non-crisis years (in both column 1 and 2), so funds flow toward high investment opportunity firms. Cash flow affects capital transfers strongly, with much larger magnitudes during the crisis years. The negative coefficient on Cash Flow implies that firms with high cash flow supply funds to other firms in the group.

These coefficients have a natural interpretation because they represent funds available for investment (unlike sales growth, which acts as a proxy that helps capture future investment opportunities). During the crisis years, for example, a $1-€$ increase in a firm's own cash flow leads, approximately, to a $0.15 €$ decline in its borrowing from the

\footnotetext{
${ }^{14}$ We report transfers from financial plus trade credit as a robustness test, but our focus is on the financial transfers. Adding trade credit reduces the sample substantially, so the results between columns 1-2 versus. 3-4 are not directly comparable, although the core result is similar. In future work, we will explore differences in transfers between financial and non-financial resources (i.e. trade credit).
} 
internal capital market; whereas a 1-€ increase in average cash elsewhere in the internal capital market raises borrowing by this firms of about $0.02-0.03 €$ (column 1 ). Thus, the marginal effect of cash generated at the firm level is much larger than that of cash flow generated by other firms in the same group; this reflects the fact that firms in a group are distinct legal and economic entities over which the holding company does not exercise unchecked control. As a result each unit has a degree of control over the use of their own cash compared to their control over cash generated elsewhere in the internal capital market. Prior to the crisis, however, we don’t see as strong a link between internal capital transfers and own cash, presumably because external finance is relatively available. The models with group x year effects suggest larger effects; these imply that a $1-€$ increase in Cash Flow (relative to the group-level average) decreases a firm's use of internal transfers by $0.20 €$ (column 2). The effect of Cash flow also increases in magnitude when we also incorporate trade credit (columns 3 and 4), while the coefficient of cash flow of other group members becomes less significant.

Panel B allows the marginal effects of Sales Growth and Cash Flow to vary by group size. These comparisons suggest, broadly, that large-group capital transfers respond more strongly to Cash flow than smaller groups, whereas small groups are more responsive to Other Cash flow than large groups. ${ }^{15}$ Moreover, the coefficients on Cash flow and on Other Cash flow for small groups are more similar to each other. We also find that small groups are unresponsive to Sales Growth in the pre-crisis period but this pattern changes in the crisis. Large groups, in contrast, consistently transfer funds to firms with high Sales Growth in both periods. These differences may reflect differences

\footnotetext{
${ }^{15}$ Despite these differences, the results below in Table 6b suggest that the effects of own and other cash flow on transfers do not differ robustly between large and small groups.
} 
in the management of the internal capital market related to agency problems, likely to be most prevalent in small, family-controlled groups. That said, exploring this dimension in detail is beyond the scope of this paper. ${ }^{16}$ For our thesis, what matters most is that both group types clearly increase the use of the internal capital market during the crisis, as the (negative) magnitude for Cash flow increases sharply between during the crisis years.

Robustness across various permutations of fixed effects helps allay the concern that omitted variables can explain our results. But, fixed effects do not address endogeneity questions that might come from reverse causality. For example, perhaps firms receiving more capital transfers are able to use the capital to generate higher sales growth. However, if transfers indeed help promote sales, this would be an indication that funds were not wasted in not sales enhancing expenditures. Nevertheless, we have also estimated the regressions in Table 5 allowing sales growth to be endogenous and using its own lagged values (once and twice) as additional instruments. These results are similar in terms of sign, size and significance and are not reported here. ${ }^{17}$ There is also a potential endogeneity issue for cash flow, based on a parallel argument. The problem is less worrisome because it would generate a positive coefficient on Cash Flow, not a negative one as we find. Reverse causality also cannot explain why Cash Flow's effect would become so much greater in magnitude during the crisis.

We have also estimated models like those in Equation (3) that allow the effects of Cash flow (along with the other variables) to vary in each year. This model thereby measures the sensitivity of capital transfers to both investment opportunities (sales growth) and cash flows on a year by year basis. Rather than report all of these

\footnotetext{
${ }^{16}$ Our data do not allow us to identify groups that are family controlled.

${ }^{17}$ Results are not reported here, but are available from the authors'.
} 
coefficients, Figure 5 summarizes the main finding by graphing the coefficient on Cash flow over time. The results suggest that the cash flow coefficient is not statistically significant before 2009, is consistently negative thereafter, and increases in magnitude as the banking problems in Italy grow worse over these years. Hence, firms seem to use the internal capital markets more aggressively as the banking system ceases to function well.

\section{Bank Health and Transfers}

The results so far merely exploit time variation in coefficients, arguing (perhaps loosely) that financial conditions deteriorate in the later years. While this is clearly true, it is crude. To focus more precisely on bank credit availability (i.e., the availability of external finance, as most is supplied by banks in Italy), we account for the health of each firm's bank(s), and we model this health directly in the capital transfer regressions. As noted earlier, bank credit has declined sharply in Italy and earlier research suggests that more distressed banks cut lending more than less distressed ones. Hence, we use Bad Loans at the end of the previous year as a measure of bank health. Specifically, we estimate models with the following structure:

$$
\begin{aligned}
& \text { Net Flow }{ }_{i, t}{ }=\beta_{1} \text { Sales Growth }_{i, t}+\beta_{2} \text { Other-Sales } \text { Growth }_{i, t} \\
& +\beta_{3} \text { Cash flow }_{i, t} / \text { Assets }_{i, t-1}+\beta_{4} \text { Other-Cash flow } \text { flt }_{i, \text { Assets }_{i, t}} \\
& +\beta_{5} \text { Bad Loans }{ }_{i, t-1} \times \text { Sales Growth }_{i, t}+\beta_{6} \text { Bad Loans }_{i, t-1} \text { x Other-Sales Growth }{ }_{i, t} \\
& +\beta_{7} \text { Bad Loans }_{i, t-1} \times \text { Cash flow }_{i, t} / \text { Assets }_{i, t-1} \\
& +\beta_{8} \text { Bad Loans }_{i, t-1} \times \text { Other-Cash flow }_{i, t} \text { Assets }_{i, t-1}+\beta_{9} \text { Bad Loans }_{i, t-1} \\
& + \text { Fixed effects }+\varepsilon_{i, t} \text {. }
\end{aligned}
$$

Equation (4) parallels Equation (3), but replaces the crisis interaction terms (which vary only by time) with Bad Loans ${ }_{i, t-1}$ and its interactions, which vary both at the firm and 
time level. Bad Loans ${ }_{i, t-1}$ equals the average ratio of bad loans to assets for firm i's bank(s) at the end of the previous year, where we weight by the amount borrowed from each bank.

Panel A of Table 6 reports the results. Columns (1) and (2) contain data for the full sample, and columns (3) and (4) contain data from just the post-crisis years. The interaction between Cash Flow and Bad Loans consistently enters with a negative and significant coefficient across all specifications, suggesting that firms with weak banks substitute more into the internal capital market. This represents very convincing evidence that the importance of internal markets increases when external debt markets become more distressed. The interaction between Bad Loans and the Other Cash Flow (as well as the Sales Growth measures), however, are typically not significant. The last two columns, which use only the post-crisis sample, get identification only from variation in bank distress, rather than from comparisons between pre- versus post-crisis years. The coefficients of the interaction between own Cash Flow and Bad Loans are of similar magnitude, and remain highly significant. Moreover, their economic significance is larger because the variation in Bad Loans increases sharply during the crisis years (recall Figure 3).

Panel B of 6 reports models with the Bad Loans interaction effects, splitting by group size as in Table 5 (Panel B). To understand the implications of these interactive models (Table 6, Panel A and B), we report Figures 6 and 7 with marginal effects of Cash Flow estimated from the pooled model (Figure 6) and again separately for large versus small groups (Figure 7). We report the marginal effects across the distribution of lagged Bad Loans, varying from 0.01 to 0.07 . The marginal effect increases as the health 
of the firm's bank(s) worsens. At the overall mean for Bad Loans in the crisis years (0.034), the marginal effect of cash flow is about -0.10 in the pooled model. For firms whose banks are one standard deviation above the mean of Bad Loans, the marginal effect approximately doubles (and it is cut in half for firms that are one standard deviation below the mean). For firms whose banks are most distressed, therefore, each 1$€$ decline in internal cash brings $0.2 €$ transfer from other group members.

Finally, over most of the distribution of bank health, the marginal effect of Cash Flow is greater for firms belonging to larger groups than for smaller ones (Figure 7). This confirms that larger groups generally respond more strongly with internal transfers when a firm suffers a negative cash flow shock. The effect becomes larger for smaller groups only when a firm's lending banks become very distressed (above the $90^{\text {th }}$ percentile).

\section{Is the Internal Capital Market Efficient?}

We have seen that group membership increases firm survival, that this effect is stronger in groups with high cash flow, and that groups move capital across firms during the crisis years. Are these actions efficiency enhancing? Or, are groups propping up weak firms (perhaps for reasons related to agency problems)? Most of our results point toward efficiency. For example, sales growth is a strong predictor of both firm survival and also, in most cases, of intra-group capital transfers. Among large groups, we find a consistent positive relationship between sales growth and capital transfers in both the precrisis and post-crisis years. For firms in small groups, this relationship is weak during the non-crisis years, but becomes positive and significant during the crisis. 
As a last test for efficiency, Table 7 reports the capital transfer models of Panel B of Table 6, after adding an interaction between the two cash flow variables (own and other) with an indicator variable equal to one for firms with above-median sales growth for that year. Efficiency in the internal capital market would imply that low cash flow firms with high sales ought to receive more intra-group transfers than low cash flow firms with low sales. In other words, Above-Median Sales*Cash flow ought to enter negatively. The opposite would be true for other cash flow, meaning that Above-Median Sales*Other Cash flow ought to enter positively.

For large groups, we find precisely these effects, and they are significant (or almost significant at conventional levels) for both dimensions of cash flow shocks (own and other). The economic effect is large, suggesting that the incremental effect of a firm's own Cash flow on internal transfers rises in (absolute) magnitude by about 0.03 to 0.08 for high-sales firms, which represents between an $80 \%$ to $120 \%$ increase above the effect of Cash flow for low sales growth firms belonging to a large group. The effect of high sales on the marginal effect of cash flow for small groups, however, enters significantly only for the Other Cash flow term in the specification without group-year fixed effects. Taken together, our results suggest that large groups make better use of their internal capital markets than small ones. ${ }^{18}$

\section{Bank Debt and Intra-Group Transfers}

Up to now we have focused on how cash is transferred within a group: the cash earned by an affiliated firm can provide financing for other member firms and this effect

\footnotetext{
${ }^{18}$ We have also tested whether capital transfers respond more to cash flow for the largest firm within groups. The evidence, which might point toward agency-based explanations for transfers, does not suggest that transfers are more sensitive to cash flow in the case of 'dominant" firms. We do not report these results here, but they are available from the authors.
} 
intensifies when external financial markets are distressed. However there is another source of funding for intra-group transfers: a firm may borrow externally and then extend that credit internally, effectively sharing their debt capacity with affiliated group members. Such sharing likely diminishes in times when credit markets are tight.

To investigate the role of external finance as funds for the internal capital market, we add bank debt to assets (from the prior year) to our specifications. Because bank debt is a dimension of firm financial policy (as are net transfers, the outcome in these models), drawing a causal inference becomes less compelling than in our earlier models that focus on operating variables (i.e., cash flow and sales growth). Hence, we introduce this variable as part of our last set of tests, with the caveat that drawing clear causal inferences is difficult. As before, we include both a firm's own bank borrowing and also bank debt to assets averaged across all other firms in the group. We focus on bank debt because it acts as the main source of external finance in Italy. Table 8 reports those specifications that allow coefficients to vary between the pre and crisis periods (as in Table 5). In Table 9, we replace the crisis/non-crisis interaction terms with interactions using Bad Loans (as in Table 6).

The results confirm, as expected, that a firm's own borrowing enters significantly with a negative sign, while that of other affiliated firms enters positively. Thus, an increase in a firm's own debt capacity increases its net transfers to other firms; conversely, an increase in the average debt capacity of other firms in the group increases net transfers to this firm. Moreover, the results in Table 8 show that these effects are attenuated during periods of crisis, when credit tightens. Thus, when external finance is less abundant - during the crisis years - group-affiliated firms actively share cash flow 
(internal funds); in contrast, when external finance is more abundant, they actively share debt capacity (external funds). These conclusions are confirmed by the results in Table 9 . When the health of the bank(s) a firm borrows from deteriorates, less of the external funds are distributed to other firms in the group. Specifically, the interaction between a firm's own bank borrowing and the health of its lenders enters positively (significantly so in most models), meaning that weakened banking mitigates the sharing of debt capacity. ${ }^{19}$

\section{Conclusions}

We have shown that group affiliation becomes very important for firm survival during the economic and financial distress that has plagued the Italian economy in recent years. This effect does not reflect differences in fundamentals or cash flow to firms. Group affiliation is not strongly correlated with changes in firm's fundamentals during the crisis years, as both affiliated and unaffiliated firms' fortunes deteriorated sharply. But group-affiliated firms have access to internal capital markets, which allows them to survive despite declining credit supplied by banks. As evidence, we show that the overall use of internal capital transfers increases sharply during the crisis years, and that those transfers move funds from relatively cash-rich to relatively cash-poor firms within the internal capital market. Transfers also respond positively to better investment opportunities. Moreover, the marginal effect of a drop in cash flow on transfers is greater for high sale growth firms belonging to large groups. We also find that the ability to

\footnotetext{
${ }^{19}$ We have also explored whether there is any evidence that lending becomes more concentrated during the crisis is a very limited number of firms. There is no clear evidence supporting this, using the CR1 or CR2 concentration ratios. Moreover we did not find evidence that the holding or sub-holdings play a large and increasing role in borrowing from the outside. For instance, the firm with the highest bank borrowing relative to total bank borrowing of the group, are holdings or sub-holdings only in approximately $20 \%$ of the cases and this percentage does not vary much over time.
} 
borrow from banks provides additional funds that are shared with other group members, but this mechanism loses its potency during the crisis period. This last finding highlights the importance of internal sources of funds combined with an active internal capital market as a substitute for banking and external finance. 


\section{References}

Albertazzi, U. and D. J. Marchetti (2010), "Credit Supply, Flight to Quality and Evergreening: an Analysis of Bank-Firm Relationships after Lehman”, Economic Working Papers, 756, Bank of Italy, Economic Research and International Relations Area.

Allison, P. D. (1982), "Discrete-Time Methods for the Analysis of Event Histories”, in S. Leinhardt (Ed.), Sociological methodology (pp. 61-98), San Francisco, Jossey-Bass.

Almeida, H., C.-S. Kim, and H.B. Kim. (2015), "Internal Capital Markets in Business Groups: Evidence from the Asian Financial Crisis”, The Journal of Finance, 70: 25392586.

Alti, A. (2003), "How Sensitive Is Investment to Cash Flow When Financing Is Frictionless?”, The Journal of Finance, 58: 707-722.

Balduzzi, P., E. Brancati, and F. Schiantarelli (2016), “Financial Markets, Banks’ Cost of Funding, and Firms’ Decisions: Lessons from Two Crises”, Boston College Working Paper 824.

Bennedsen, M., K. M. Nielsen, F. Perez-Gonzalez, and D. Wolfenson (2007), "Inside the Family Firm”, Quarterly Journal of Economics, 122: 647-691.

Bianchi M., M. Bianco, S. Giacomelli, A. M. Pacces, and S. Trento (2005), Proprietà e Controllo delle Imprese in Italia, Bologna, Il Mulino.

Bianchi M., M. Bianco, S. Giacomelli, P. Maggio, V. Novembre, L. Russo, P. Santella and R. Signoretti (2008), "The Evolution of Ownership and Control Structure in Italy in the Last 15 Years", Convegno su "Corporate Governance in Italia: a 10 anni dal Testo Unico della Finanza”, 11 dicembre 2008, Roma, Banca d’Italia.

Bofondi, M., L. Carpinelli, and E. Sette (2013), “Credit Supply During a Sovereign Debt Crisis”, Economic Working Papers, 909, Bank of Italy, Economic Research and International Relations Area.

Bolton, P., X. Freixas, L. Gambacorta, and P. E. Mistrulli (2013), "Relationship and Transaction Lending in a Crisis”, Economic Working Papers, 917, Bank of Italy, Economic Research and International Relations Area.

Cannari L., and Gola C. (1996), "La Diffusione dei Gruppi Industriali in Italia” in I gruppi di società: Atti del Convegno internazionale di studi di Venezia, 16-18 novembre 1995, Milano, Giuffrè, 2: 813-35.

Cingano, F., F. Manaresi and E. Sette (2016), "Does Credit Crunch Investment Down? New Evidence on the Real Effects of the Bank Lending Channel”, The Review of Financial Studies, 29: 2737 - 2773. 
De Marco, F. (2015), "Bank Lending and the Sovereign Debt Crisis", Bocconi University.

Gopalan, R., V. Nanda, and A. Seru. (2007), “Affiliated Firms and Financial Support: Evidence from Indian Business Groups”, Journal of Financial Economics, 86: 759-795.

La Porta, R. L., F. Lopez-de-Silanes, and A. Shleifer (1999), "Corporate Ownership around the World”, The Journal of Finance, 54: 471-517.

Lamont, O. (1997), "Cash Flow and Investment: Evidence from Internal Capital Markets”, The Journal of Finance, 52: 83-109.

Larry H. P. Lang, and René M. Stulz (1994), “Tobin's Q, Corporate Diversification, and Firm Performance”, Journal of Political Economy, 102: 1248-1280.

Khanna, T. (2000), "Business Groups and Social Welfare in Emerging Markets: Existing Evidence and Unanswered Questions”, European Economic Review, 44:748761.

Kuppuswamy, V. and B. Villalonga (2015), "Does Diversification Create Value in the Presence of External Financing Constraints? Evidence from the 2007-2009 Financial Crisis,” Management Science, 62, 905-923.

Matvos, G. and A. Seru (2014), Resource Allocation within Firms and Financial Market Dislocation: Evidence from Diversified Conglomerates, The Review of Financial Studies, 2: 1143-1189.

Matvos, G., A. Seru, and R. Silva (2016), "Financial Market Frictions and Diversification”, available at SSRN: https://ssrn.com/abstract=2857986

Popov, A. and N. van Horen (2013), “The Impact of Sovereign Debt Exposure on Bank Lending: Evidence from the European Debt Crisis”, DNB Working Papers, 382, Netherlands Central Bank, Research Department.

Santioni, R. (2011), “Corporate Groups in Italy: a Macro-Regions Analysis 1998-2006, Workshop on Economic integration between the Mezzogiorno and the Centre North", Bank of Italy.

Santioni R., and I. Supino (2017), “The Internal Capital Markets Under Financial Constraints”, mimeo, Bank of Italy.

Scharfstein David S, and Jeremy C Stein (2000), “The Dark Side of Internal Capital Markets: Divisional Rent-Seeking and Inefficient Investment”, The Journal of Finance, 55: 2537-2564.

Schiantarelli, F. and A. Sembenelli (2000), "Form of Ownership and Financial Constraints: Panel Data Evidence From Flow of Funds and Investment Equations”, Empirica, 27: 175-192. 
Schiantarelli, F., M. Stacchini, and P. Strahan (2016), "Bank Quality, Judicial Efficiency and Borrower Runs: Loan Repayment Delays in Italy”, Economic Working Papers, 1072, Bank of Italy, Economic Research and International Relations Area.

Schoar, A. (2002), "Effects of Corporate Diversification on Productivity”, The Journal of Finance, 57: 2379-2403.

Shin, Hyun-Han and René M. Stulz (1998), “Are Internal capital Markets Efficient?”, The Quarterly Journal of Economics, 113: 531-552.

Singer, J. D., and J. B.Willett (1993), “It’s About Time: Using Discrete-Time Survival Analysis to Study Duration and the Timing of Events”, Journal of Educational Statistics, 18: 155-195.

Stein Jeremy C (1997), “Internal Capital Markets and the Competition for Corporate Resources”, The Journal of Finance, 52: 111-133.

Villalonga, B. (2004), "Does Diversification Cause the "Diversification Discount"?" Financial Management, 33: 5-27.

Whited, Toni M. (2001), "Is It Inefficient Investment That Causes the Diversification Discount?" The Journal of Finance, 56: 1667-1691. 


\section{Data appendix}

\section{Bank level variables - Source: Supervisory Reports, Bank of Italy}

(Bank level) Bad loans: exposures to insolvent counterparties (even if not legally ascertained or formally written off); thousands of euros.

Total assets: bank's total assets; thousands of euros.

Bad loans ratio: bad loans/total assets; thousands of euros.

\section{Loan quality and lending relationship - Source: Credit Register, Bank of Italy}

(Firm-bank level) Bad loans (as explanatory variable) end of year weighted average of the lending banks' ratio of bad loans to total assets (bad loans ratio), where the weights equal the fraction of credit received by a given firm from each of its banks.

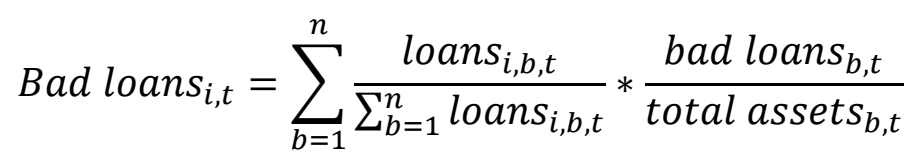

\section{Firm level variables - Source: Balance sheet register (Cerved)}

Sales growth: the annual percentage change in real sales; industry GDP deflator used to deflate nominal sales.

Cash flow: net income minus extraordinary items plus depreciation and amortization divided by end of previous year total assets; firm, year-level.

Other sales growth: the annual percentage change in real sales of all other firms affiliated with the same group.

Other cash flow: the average of cash flow for all other firms affiliated with the same group divided by end of previous year total assets.

Total assets: firm's total assets; thousands of euros. 
Bank debt: total amount of financial debt owed by a given firm towards the banking system; thousands of euros.

Total borrowing: total amount of financial debt owed by a given firm in thousands of euros.

Gross intra-group financial debt: total amount of financial debt owed by a given firm to all other firms affiliated with the same group; thousands of euros.

Intra-group net financial position: total amount of financial debt owed by a given firm to all other firms affiliated with the same group divided by end of previous year total assets, net of credit given.

Intra-group net trade position: total amount of trade debt owed by a given firm to all other firms affiliated with the same group, net of credit given firm divided by end of previous year total assets.

Intra-group net position (total): intra-group net financial position plus intra-group net trade position divided by end of previous year total assets.

Employees: number of employees.

Age: the number of years from date of incorporation of the company.

Asset ratio: total assets of the firm/total assets of all firms affiliated with the same group. 
Table 1: Summary Statistics

This table reports summary statistics for the Universe of Firms based in Italy. The description of variables and their data sources are provided in the Appendix.

\begin{tabular}{|c|c|c|c|c|c|c|c|c|c|c|c|c|c|c|c|}
\hline \multirow[b]{4}{*}{ Panal A. Rofore the Cricis } & \multicolumn{5}{|c|}{ Small domestic groups } & \multicolumn{5}{|c|}{ Large domestic groups } & \multicolumn{5}{|c|}{ Unaffiliated } \\
\hline & \multirow[t]{2}{*}{ Mean } & \multirow{2}{*}{$\begin{array}{l}\text { Std. } \\
\text { Dev. }\end{array}$} & \multicolumn{3}{|c|}{ Percentiles } & \multirow[t]{2}{*}{ Mean } & \multirow{2}{*}{$\begin{array}{l}\text { Std. } \\
\text { Dev. }\end{array}$} & \multicolumn{3}{|c|}{ Percentiles } & \multirow[t]{2}{*}{ Mean } & \multirow{2}{*}{$\begin{array}{l}\text { Std. } \\
\text { Dev. }\end{array}$} & \multicolumn{3}{|c|}{ Percentiles } \\
\hline & & & $25^{\text {th }}$ & $50^{\text {th }}$ & $75^{\text {th }}$ & & & $25^{\text {th }}$ & $50^{\text {th }}$ & $75^{\text {th }}$ & & & $25^{\text {th }}$ & $50^{\text {th }}$ & $75^{\text {th }}$ \\
\hline & & & & & & & & & & & & & & & \\
\hline $\begin{array}{l}\text { Sales Growth } \\
\end{array}$ & 0.121 & 0.594 & -0.159 & 0.003 & 0.218 & 0.110 & 0.507 & -0.090 & 0.025 & 0.178 & 0.100 & 0.494 & -0.144 & 0.013 & 0.214 \\
\hline Total assets & 2,177 & 6,442 & 326 & 908 & 2,354 & 37,611 & 727,964 & 1,499 & 5,919 & 16,480 & 1,923 & 57,676 & 149 & 417 & 1,165 \\
\hline Cash Flow/Assets & 0.036 & 0.077 & 0.000 & 0.028 & 0.071 & 0.041 & 0.072 & 0.006 & 0.034 & 0.076 & 0.046 & 0.099 & 0.001 & 0.036 & 0.091 \\
\hline Total borrowing/Assets & 0.343 & 0.329 & 0.009 & 0.268 & 0.581 & 0.330 & 0.289 & 0.057 & 0.288 & 0.519 & 0.294 & 0.305 & 0.000 & 0.207 & 0.499 \\
\hline Intra-Group Net Fin. Position / Assets & 0.018 & 0.220 & -0.076 & 0.001 & 0.080 & 0.034 & 0.204 & -0.046 & 0.001 & 0.081 & & & & & \\
\hline Intra-Group Net Positions (total) /Assets & -0.021 & 0.243 & -0.134 & -0.018 & 0.069 & -0.018 & 0.237 & -0.127 & -0.019 & 0.070 & & & & & \\
\hline Other Sales Growth & 0.076 & 0.460 & -0.159 & 0.000 & 0.202 & 0.065 & 0.308 & -0.061 & 0.037 & 0.146 & & & & & \\
\hline Other Cash Flow/Assets & 0.122 & 0.295 & 0.001 & 0.023 & 0.105 & 0.262 & 0.454 & 0.004 & 0.047 & 0.279 & & & & & \\
\hline Bad Loans/Assets & 0.022 & 0.012 & 0.013 & 0.019 & 0.027 & 0.023 & 0.012 & 0.015 & 0.020 & 0.029 & & & & & \\
\hline Number of firms & \multicolumn{5}{|c|}{116,727} & \multicolumn{5}{|c|}{43,792} & \multicolumn{5}{|c|}{362,665} \\
\hline Panel B: During the Crisis & & & & & & & & & & & & & & & \\
\hline Sales Growth & 0.034 & 0.510 & -0.218 & -0.023 & 0.144 & 0.024 & 0.455 & -0.171 & -0.016 & 0.118 & 0.015 & 0.419 & -0.202 & -0.024 & 0.139 \\
\hline Total assets & 2,551 & 8,840 & 339 & 953 & 2,519 & 42,037 & 771,877 & 1,714 & 6,422 & 18,339 & 1,801 & 61,077 & 151 & 415 & 1,141 \\
\hline Cash Flow/Assets & 0.030 & 0.079 & -0.002 & 0.025 & 0.066 & 0.032 & 0.076 & 0.000 & 0.029 & 0.069 & 0.038 & 0.098 & -0.001 & 0.031 & 0.082 \\
\hline Total borrowing/Assets & 0.325 & 0.305 & 0.021 & 0.259 & 0.549 & 0.312 & 0.278 & 0.047 & 0.267 & 0.497 & 0.277 & 0.284 & 0.000 & 0.196 & 0.470 \\
\hline Intra-Group Net Fin. Position/Assets & 0.011 & 0.220 & -0.084 & 0.002 & 0.078 & 0.031 & 0.209 & -0.051 & 0.001 & 0.089 & & & & & \\
\hline Intra-Group Net Position (total) /Assets & -0.030 & 0.244 & -0.147 & -0.020 & 0.061 & -0.017 & 0.242 & -0.131 & -0.019 & 0.078 & & & & & \\
\hline Other Sales Growth & 0.003 & 0.401 & -0.207 & -0.023 & 0.131 & -0.008 & 0.300 & -0.143 & -0.015 & 0.096 & & & & & \\
\hline Other Cash Flow /Assets & 0.103 & 0.259 & 0.000 & 0.020 & 0.096 & 0.214 & 0.385 & 0.002 & 0.036 & 0.247 & & & & & \\
\hline Bad Loans/Assets & 0.039 & 0.022 & 0.023 & 0.034 & 0.050 & 0.040 & 0.021 & 0.025 & 0.035 & 0.051 & & & & & \\
\hline Number of firms & & & 156,221 & & & & & 44,341 & & & & & 444,021 & & \\
\hline
\end{tabular}

Notes: (1) All figures obtained after winsorizing at the $5^{\text {th }}$ and $95^{\text {th }}$ percentiles. (2) Total borrowing includes all forms of external and internal (gross) financial debt.

(3) Intra-group net financial position includes intra-group financial borrowing minus intra-group financial lending. (4) Intra-group net position (total) includes intra-group financial borrowing minus lending plus intra-group net trade debt (accounts payable minus accounts receivable). 


\section{Table 2: Transition matrix for the Universe of Italian Firms}

This table reports transition probabilities for the Universe of Firms based in Italy over two, nonoverlapping periods: 2006 to 2010 and 2010 to 2014. The description of variables and their data sources are provided in the Appendix.

\begin{tabular}{|c|c|c|c|c|c|c|}
\hline & & $\begin{array}{l}\text { Unaffiliated } \\
\text { firms }\end{array}$ & $\begin{array}{c}\text { Small } \\
\text { domestic } \\
\text { groups }\end{array}$ & $\begin{array}{c}\text { Large } \\
\text { domestic } \\
\text { groups }\end{array}$ & $\begin{array}{l}\text { Foreign } \\
\text { groups }\end{array}$ & $\begin{array}{c}\text { No } \\
\text { balance } \\
\text { sheet }\end{array}$ \\
\hline & & & & 2010 & & \\
\hline & Unaffiliated firms & $59.49 \%$ & $6.62 \%$ & $1.43 \%$ & $0.12 \%$ & $32.34 \%$ \\
\hline & $\begin{array}{l}\text { Small domestic } \\
\text { groups }\end{array}$ & $13.90 \%$ & $53.54 \%$ & $1.18 \%$ & $0.14 \%$ & $31.23 \%$ \\
\hline 2006 & $\begin{array}{l}\text { Large domestic } \\
\text { groups }\end{array}$ & $10.76 \%$ & $4.59 \%$ & $58.15 \%$ & $0.96 \%$ & $25.54 \%$ \\
\hline & Foreign groups & $8.03 \%$ & $3.69 \%$ & $7.18 \%$ & $50.99 \%$ & $30.12 \%$ \\
\hline & New firms & $72.24 \%$ & $22.96 \%$ & $4.37 \%$ & $0.43 \%$ & $0.00 \%$ \\
\hline & & & & 2014 & & \\
\hline & Unaffiliated firms & $54.55 \%$ & $4.80 \%$ & $0.82 \%$ & $0.06 \%$ & $39.77 \%$ \\
\hline & $\begin{array}{l}\text { Small domestic } \\
\text { groups }\end{array}$ & $10.26 \%$ & $50.74 \%$ & $0.94 \%$ & $0.08 \%$ & $37.97 \%$ \\
\hline 2010 & $\begin{array}{l}\text { Large domestic } \\
\text { groups }\end{array}$ & $6.57 \%$ & $4.16 \%$ & $59.70 \%$ & $0.70 \%$ & $28.88 \%$ \\
\hline & Foreign groups & $6.19 \%$ & $3.19 \%$ & $6.19 \%$ & $55.34 \%$ & $29.10 \%$ \\
\hline & New firms & $72.07 \%$ & $23.27 \%$ & $4.22 \%$ & $0.44 \%$ & $0.00 \%$ \\
\hline
\end{tabular}




\section{Table 3A: Firm Failure by Group Affiliation}

This table reports a discrete-time logistic hazard model for firms existing in 2006, from that year until 2013. Firms that exit the sample during this period are modelled as failures, while those that survive are right-censored. Sample includes both group-affiliated and independent firms. Firms that enter the sample after 2006 are excluded. Standard errors clustered by firm.

\begin{tabular}{lcccc}
\hline \multicolumn{1}{c}{ Dependent Variable } & \multicolumn{4}{c}{ Firm Failure } \\
\cline { 2 - 5 } Group*No crisis & $(1)$ & $(2)$ & $(3)$ & $(4)$ \\
\cline { 2 - 5 } & $-0.1001^{* * *}$ & $-0.1069^{* * *}$ & $-0.0857^{* * *}$ & $-0.0892^{* * *}$ \\
Group*Crisis & $(0.0084)$ & $(0.0093)$ & $(0.0085)$ & $(0.0094)$ \\
& $-0.3137^{* * *}$ & $-0.2452^{* * *}$ & $-0.3246^{* * *}$ & $-0.2578^{* * *}$ \\
Cash flow ${ }_{\mathrm{t}-1} /$ Asset $_{\mathrm{t}-2}$ & $(0.0077)$ & $(0.0080)$ & $(0.0078)$ & $(0.0082)$ \\
& - & $-6.5068^{* * *}$ & - & $-6.5117^{* * *}$ \\
Sales growth & & $(0.0408)$ & & $(0.0410)$ \\
& - & $-0.6347^{* * *}$ & - & $-0.6377^{* * *}$ \\
Log age & & $(0.0099)$ & & $(0.0100)$ \\
& $-0.2733^{* * *}$ & $-0.3279^{* * *}$ & $-0.2730 * * *$ & $-0.3278^{* * *}$ \\
& $(0.0025)$ & $(0.0028)$ & $(0.0025)$ & $(0.0028)$ \\
\hline Year FE & & & & No \\
Industry FE & Yes & Yes & No & No \\
Location FE & Yes & Yes & No & No \\
Firm size FE & Yes & Yes & No & No \\
Industry*Year FE & Yes & Yes & No & Yes \\
Location*Year FE & No & No & Yes & Yes \\
Firm size*Year FE & No & No & Yes & Yes \\
Observations & No & No & Yes & $1,692,124$ \\
\hline
\end{tabular}




\section{Table 3B: Firm Failure by Group Affiliation and Firm Size}

This table reports a discrete-time logistic hazard model for firms existing in 2006, from that year until 2013. Firms that exit the sample during this period are modelled as failures, while those that survive are right-censored. Sample includes both group-affiliated and independent firms. Firms that enter the sample after 2006 are excluded. Standard errors clustered by firm.

\begin{tabular}{|c|c|c|c|c|}
\hline \multirow[t]{2}{*}{ Dependent Variable } & \multicolumn{4}{|c|}{ Firm Failure } \\
\hline & (1) & (2) & (3) & (4) \\
\hline Large Independent*No crisis & $\begin{array}{c}-0.7494 * * * \\
(0.0332)\end{array}$ & $\begin{array}{c}-0.6751^{* * *} \\
(0.0356)\end{array}$ & $\begin{array}{c}-0.7619 * * * \\
(0.0333)\end{array}$ & $\begin{array}{c}-0.6933^{* * *} \\
(0.0356)\end{array}$ \\
\hline Large Independent*Crisis & $\begin{array}{c}-0.3689 * * * \\
(0.0245)\end{array}$ & $\begin{array}{c}-0.3341 * * * \\
(0.0277)\end{array}$ & $\begin{array}{c}-0.3553 * * * \\
(0.0246)\end{array}$ & $\begin{array}{c}-0.3197 * * * \\
(0.0277)\end{array}$ \\
\hline Small Firms in Small Group*No crisis & $\begin{array}{c}-0.1156^{* * *} \\
(0.0093)\end{array}$ & $\begin{array}{c}-0.1341^{* * *} \\
(0.0103)\end{array}$ & $\begin{array}{c}-0.1079 * * * \\
(0.0094)\end{array}$ & $\begin{array}{c}-0.1229 * * * \\
(0.0104)\end{array}$ \\
\hline Small Firms in Small Group*Crisis & $\begin{array}{c}-0.2908^{* * *} \\
(0.0084)\end{array}$ & $\begin{array}{c}-0.2281^{* * *} \\
(0.0088)\end{array}$ & $\begin{array}{c}-0.2963 * * * \\
(0.0085)\end{array}$ & $\begin{array}{c}-0.2367 * * * \\
(0.0089)\end{array}$ \\
\hline Small Firms in Large Group*No crisis & $\begin{array}{l}-0.0102 \\
(0.0168)\end{array}$ & $\begin{array}{c}0.0211 \\
(0.0187)\end{array}$ & $\begin{array}{l}-0.0032 \\
(0.0169)\end{array}$ & $\begin{array}{c}0.0317^{*} \\
(0.0189)\end{array}$ \\
\hline Small Firms in Large Group*Crisis & $\begin{array}{c}-0.3423 * * * \\
(0.0166)\end{array}$ & $\begin{array}{c}-0.2815 * * * \\
(0.0171)\end{array}$ & $\begin{array}{c}-0.3451 * * * \\
(0.0166)\end{array}$ & $\begin{array}{c}-0.2864 * * * \\
(0.0171)\end{array}$ \\
\hline Large Firms in Large Group*No crisis & $\begin{array}{c}-0.9886 * * * \\
(0.0301)\end{array}$ & $\begin{array}{c}-0.8337 * * * \\
(0.0313)\end{array}$ & $\begin{array}{c}-0.9930 * * * \\
(0.0302)\end{array}$ & $\begin{array}{c}-0.8501^{* * * *} \\
(0.0314)\end{array}$ \\
\hline Large Firms in Large Group*Crisis & $\begin{array}{c}-1.2425 * * * \\
(0.0281)\end{array}$ & $\begin{array}{c}-0.9698 * * * \\
(0.0284)\end{array}$ & $\begin{array}{c}-1.2367 * * * \\
(0.0282)\end{array}$ & $\begin{array}{c}-0.9567 * * * \\
(0.0284)\end{array}$ \\
\hline Cash flow $_{\mathrm{t}-1} /$ Asset $_{\mathrm{t}-2}$ & - & $\begin{array}{c}-6.5099 * * * \\
(0.0409)\end{array}$ & - & $\begin{array}{c}-6.5165^{* * *} \\
(0.0410)\end{array}$ \\
\hline Sales growth t-1 $_{1}$ & - & $\begin{array}{c}-0.6360^{* * * *} \\
(0.0099)\end{array}$ & - & $\begin{array}{c}-0.6389 * * * \\
(0.0100)\end{array}$ \\
\hline Log age & $\begin{array}{c}-0.2742 * * * \\
(0.0025)\end{array}$ & $\begin{array}{c}-0.3287 * * * \\
(0.0028)\end{array}$ & $\begin{array}{c}-0.2740 * * * \\
(0.0025)\end{array}$ & $\begin{array}{c}-0.3283^{* * *} * \\
(0.0028)\end{array}$ \\
\hline Year FE & Yes & Yes & No & No \\
\hline Industry FE & Yes & Yes & No & No \\
\hline Location FE & Yes & Yes & No & No \\
\hline Industry*Year FE & No & No & Yes & Yes \\
\hline Location*Year FE & No & No & Yes & Yes \\
\hline Observations & $1,843,836$ & $1,692,124$ & $1,843,836$ & $1,692,124$ \\
\hline
\end{tabular}




\section{Table 4: Firm Failure and Access to Group-Level Cash Flow and Sales Growth}

This table reports a discrete-time logistic hazard model for firms existing in 2006, from that year until 2013. Firms that exit the sample during this period are modeled as failures, while those that survive are right-censored. Sample includes only group-affiliated firms. Firms that enter the sample after 2006 are excluded. Standard errors clustered by firm.

\begin{tabular}{|c|c|c|c|}
\hline \multirow{3}{*}{ Dependent Variable } & \multicolumn{3}{|c|}{ Firm Failure } \\
\hline & (1) & (2) & (3) \\
\hline & Pooled & Small Groups & Large Groups \\
\hline No Crisis & & & $-0.2521 * * *$ \\
\hline & - & - & $(0.0688)$ \\
\hline Crisis & & & $-0.2014 * * *$ \\
\hline & - & - & $(0.0677)$ \\
\hline Own Fundamentals: & & & \\
\hline Sales growth $\mathrm{t}_{\mathrm{t}-1} *$ No Crisis & $\begin{array}{c}-0.3926 * * * \\
(0.0270)\end{array}$ & $\begin{array}{c}-0.3689 * * * \\
(0.0329)\end{array}$ & $\begin{array}{c}-0.4296 * * * \\
(0.0463)\end{array}$ \\
\hline Sales growth t-1 $*$ Crisis & $\begin{array}{c}-0.6204^{* * * *} \\
(0.0410)\end{array}$ & $\begin{array}{c}-0.5213^{* * *} \\
(0.0453)\end{array}$ & $\begin{array}{c}-0.8680 * * * \\
(0.0843)\end{array}$ \\
\hline Cash flow $_{\mathrm{t}-1} /$ Asset $_{\mathrm{t}-2} *$ No Crisis & $\begin{array}{c}-5.9441 * * * \\
(0.1696)\end{array}$ & $\begin{array}{c}-6.8633 * * * \\
(0.2199)\end{array}$ & $\begin{array}{l}-4.4648^{* * *} \\
(0.2604)\end{array}$ \\
\hline Cash flow $_{\mathrm{t}-1} /$ Asset $_{\mathrm{t}-2} *$ Crisis & $\begin{array}{c}-9.2577^{* * * *} \\
(0.1779)\end{array}$ & $\begin{array}{c}-9.0209 * * * \\
(0.2132)\end{array}$ & $\begin{array}{l}-9.2279 * * * \\
(0.3108)\end{array}$ \\
\hline Other Fundamentals: & & & \\
\hline Other Sales growth $\mathrm{t}_{\mathrm{t}-1} *$ No Crisis & $\begin{array}{l}-0.0073 \\
(0.0295)\end{array}$ & $\begin{array}{c}0.0185 \\
(0.0325)\end{array}$ & $\begin{array}{l}-0.1181^{*} \\
(0.0682)\end{array}$ \\
\hline Other Sales growth $\mathrm{t}_{\mathrm{t}-1}{ }^{*}$ Crisis & $\begin{array}{c}-0.1163^{* * * *} \\
(0.0327)\end{array}$ & $\begin{array}{c}-0.0849 * * \\
(0.0357)\end{array}$ & $\begin{array}{c}-0.2640 * * * \\
(0.0733)\end{array}$ \\
\hline Other Cash flow $\mathrm{t}_{\mathrm{t}-1} /$ Asset $_{\mathrm{t}-2} *$ No Crisis & $\begin{array}{c}-0.1710^{* * * *} \\
(0.0326)\end{array}$ & $\begin{array}{c}-0.2492^{* * *} \\
(0.0497)\end{array}$ & $\begin{array}{c}-0.1279 * * * \\
(0.0425)\end{array}$ \\
\hline Other Cash flow t $-1 /$ Asset $_{\mathrm{t}-2}{ }^{*}$ Crisis & $\begin{array}{c}-0.4495^{* * *} \\
(0.0458)\end{array}$ & $\begin{array}{l}-0.5984 * * * \\
(0.0658)\end{array}$ & $\begin{array}{l}-0.2842 * * * \\
(0.0628)\end{array}$ \\
\hline No Crisis*Log (asset ratio) $)_{\mathrm{t}-1}$ & $\begin{array}{c}-0.2532^{* * *} \\
(0.0067)\end{array}$ & $\begin{array}{c}-0.2390 * * * \\
(0.0097)\end{array}$ & $\begin{array}{l}-0.2719 * * * \\
(0.0099)\end{array}$ \\
\hline Crisis*Log (asset ratio) $)_{\mathrm{t}-1}$ & $\begin{array}{c}-0.2180 * * * \\
(0.0080)\end{array}$ & $\begin{array}{c}-0.3213^{* * *} \\
(0.0123)\end{array}$ & $\begin{array}{l}-0.1908^{* * *} \\
(0.0119)\end{array}$ \\
\hline No Crisis*Log age & $\begin{array}{c}-0.2886 * * * \\
(0.0115)\end{array}$ & $\begin{array}{c}-0.3059 * * * \\
(0.0141)\end{array}$ & $\begin{array}{l}-0.2588^{* * *} \\
(0.0192)\end{array}$ \\
\hline Crisis*Log age & $\begin{array}{c}-0.2958^{* * *} \\
(0.0103)\end{array}$ & $\begin{array}{c}-0.2978 * * * \\
(0.0124)\end{array}$ & $\begin{array}{c}-0.2490 * * * \\
(0.0182)\end{array}$ \\
\hline Industry * Year FE & Yes & & \\
\hline Location * Year FE & Yes & & \\
\hline Firm size * Year FE & Yes & & \\
\hline Firm Clustered St. Errors & Yes & & \\
\hline Observations & 338,814 & 33 & \\
\hline
\end{tabular}




\section{Table 5A: Intra-Group Capital Transfers}

This table reports regressions of intra-group transfers as a function of sales growth and cash flow at the firm-level and cash flow and sales growth for other firms affiliated with the same group. Columns 1 and 2 include just net financial transfers, while columns 3 and 4 incorporate net trade position. Increases in the dependent variable reflect increased borrowing from group-affiliated sources.

\begin{tabular}{|c|c|c|c|c|}
\hline \multirow[t]{2}{*}{ Dependent Variable } & \multicolumn{2}{|c|}{$\begin{array}{l}\text { Intra-Group Financial } \\
\text { Position }_{\mathrm{t}} / \text { Assets }_{\mathrm{t}-1}\end{array}$} & \multicolumn{2}{|c|}{$\begin{array}{l}\text { Intra-Group Financial and } \\
\text { Trade Position }{ }_{\mathrm{t}} \text { Assets }_{\mathrm{t}-1}\end{array}$} \\
\hline & (1) & $(2)$ & (3) & (4) \\
\hline Sales growth ${ }_{\mathrm{t}}{ }^{\text {No Crisis }}$ & $\begin{array}{c}0.0087 * * * \\
(0.0016)\end{array}$ & $\begin{array}{c}0.0068^{* *} \\
(0.0034)\end{array}$ & $\begin{array}{l}0.0055^{*} \\
(0.0030)\end{array}$ & $\begin{array}{c}0.0073 \\
(0.0051)\end{array}$ \\
\hline Sales growth ${ }_{\mathrm{t}}{ }^{*}$ Crisis & $\begin{array}{l}0.0075^{* * *} \\
(0.0011)\end{array}$ & $\begin{array}{c}0.0112^{* * *} \\
(0.0022)\end{array}$ & $\begin{array}{l}0.0046 * * \\
(0.0019)\end{array}$ & $\begin{array}{l}0.0057 * \\
(0.0035)\end{array}$ \\
\hline Cash flow $_{\mathrm{t}} /$ Asset $_{\mathrm{t}-1} *$ No Crisis & $\begin{array}{l}-0.0094 \\
(0.0169)\end{array}$ & $\begin{array}{c}-0.0194 \\
(0.0283)\end{array}$ & $\begin{array}{c}-0.0670 * * \\
(0.0262)\end{array}$ & $\begin{array}{c}-0.0687^{*} \\
(0.0411)\end{array}$ \\
\hline Cash flow $_{t} /$ Asset $_{\mathrm{t}-1}{ }^{*}$ Crisis & $\begin{array}{c}-0.1483 * * * \\
(0.0119)\end{array}$ & $\begin{array}{c}-0.2038 * * * \\
(0.0195)\end{array}$ & $\begin{array}{c}-0.2648 * * * \\
(0.0179)\end{array}$ & $\begin{array}{c}-0.3222 * * * \\
(0.0272)\end{array}$ \\
\hline Other Fundamentals: & & & & \\
\hline Other Sales growth $_{t}{ }^{*}$ No Crisis & $\begin{array}{l}-0.0020 \\
(0.0016)\end{array}$ & $\begin{array}{l}-0.0091 \\
(0.0060)\end{array}$ & $\begin{array}{l}-0.0050 * \\
(0.0027)\end{array}$ & $\begin{array}{c}0.0039 \\
(0.0106)\end{array}$ \\
\hline Other Sales growth ${ }_{t}^{*}$ Crisis & $\begin{array}{c}0.0013 \\
(0.0011)\end{array}$ & $\begin{array}{c}0.0053 \\
(0.0040)\end{array}$ & $\begin{array}{c}0.0028 \\
(0.0020)\end{array}$ & $\begin{array}{c}0.0061 \\
(0.0066)\end{array}$ \\
\hline Other Cash flow ${ }_{t} /$ Asset $_{\mathrm{t}-1} *$ No Crisis & $\begin{array}{c}0.0330 * * * \\
(0.0045)\end{array}$ & $\begin{array}{c}0.0409 * * * \\
(0.0062)\end{array}$ & $\begin{array}{l}0.0111^{*} \\
(0.0067)\end{array}$ & $\begin{array}{l}0.0147 * \\
(0.0089)\end{array}$ \\
\hline Other Cash flow ${ }_{\mathrm{t}} /$ Asset $_{\mathrm{t}-1}{ }^{*}$ Crisis & $\begin{array}{c}0.0230 * * * \\
(0.0043)\end{array}$ & $\begin{array}{c}0.0188 * * * \\
(0.0061)\end{array}$ & $\begin{array}{c}0.0100 \\
(0.0065)\end{array}$ & $\begin{array}{l}-0.0014 \\
(0.0089)\end{array}$ \\
\hline Industry*Year FE & Yes & Yes & Yes & Yes \\
\hline Location*Year FE & Yes & Yes & Yes & Yes \\
\hline Group*Year FE & No & Yes & No & Yes \\
\hline Firm FE & Yes & Yes & Yes & Yes \\
\hline Group*Year \& Firm Clustered St. Errors & Yes & Yes & Yes & Yes \\
\hline Observations & 171,102 & 110,303 & 100,459 & 67,317 \\
\hline R-squared & 0.788 & 0.858 & 0.789 & 0.863 \\
\hline
\end{tabular}




\section{Table 5B: Intra-Group Capital Transfers, by group size}

This table reports regressions of intra-group transfers as a function of sales growth and cash flow at the firm-level and cash flow and sales growth for other firms affiliated with the same group. Columns 1 and 2 represent one regression, and columns 3 and 4 represent the other. Increases in the dependent variable reflect increased borrowing from group-affiliated sources.

\begin{tabular}{|c|c|c|c|c|}
\hline \multirow[t]{3}{*}{ Dependent Variable } & \multicolumn{4}{|c|}{ Intra-Group Financial Position $_{\mathrm{t}} /$ Assets $_{\mathrm{t}-1}$} \\
\hline & $(1)$ & $(2)$ & (3) & (4) \\
\hline & $\begin{array}{c}\text { Small } \\
\text { Groups }\end{array}$ & $\begin{array}{l}\text { Large } \\
\text { Groups }\end{array}$ & $\begin{array}{c}\text { Small } \\
\text { Groups }\end{array}$ & $\begin{array}{l}\text { Large } \\
\text { Groups }\end{array}$ \\
\hline \multicolumn{5}{|l|}{ Own Fundamentals: } \\
\hline Sales growth ${ }_{\mathrm{t}} *$ No Crisis & $\begin{array}{c}-0.0003 \\
(0.0021)\end{array}$ & $\begin{array}{c}0.0141 * * * \\
(0.0023)\end{array}$ & $\begin{array}{l}-0.0153 \\
(0.0125)\end{array}$ & $\begin{array}{c}0.0086 * * \\
(0.0036)\end{array}$ \\
\hline Sales growth $_{t}{ }^{*}$ Crisis & $\begin{array}{c}0.0058^{* * *} \\
(0.0013)\end{array}$ & $\begin{array}{c}0.0090 * * * \\
(0.0017)\end{array}$ & $\begin{array}{c}0.0130 * * * \\
(0.0046)\end{array}$ & $\begin{array}{c}0.0124 * * * \\
(0.0026)\end{array}$ \\
\hline Cash flow $_{\mathrm{t}} /$ Asset $_{\mathrm{t}-1} *$ No Crisis & $\begin{array}{c}0.0633^{* *} \\
(0.0275)\end{array}$ & $\begin{array}{c}-0.0357^{*} \\
(0.0207)\end{array}$ & $\begin{array}{l}0.1200 * \\
(0.0687)\end{array}$ & $\begin{array}{c}-0.0430 \\
(0.0314)\end{array}$ \\
\hline Cash flow $_{t} /$ Asset $_{\mathrm{t}-1}{ }^{*}$ Crisis & $\begin{array}{c}-0.0749 * * * \\
(0.0166)\end{array}$ & $\begin{array}{c}-0.1864 * * * \\
(0.0157)\end{array}$ & $\begin{array}{c}-0.0679 * * \\
(0.0337)\end{array}$ & $\begin{array}{c}-0.2333^{* * *} \\
(0.0231)\end{array}$ \\
\hline \multicolumn{5}{|l|}{ Other Fundamentals: } \\
\hline Other Sales growth ${ }_{t}^{*}$ No Crisis & $\begin{array}{l}-0.0027 \\
(0.0023)\end{array}$ & $\begin{array}{c}-0.0025 \\
(0.0022)\end{array}$ & $\begin{array}{c}-0.0370 * * \\
(0.0174)\end{array}$ & $\begin{array}{l}-0.0109 \\
(0.0075)\end{array}$ \\
\hline Other Sales growth ${ }_{\mathrm{t}}{ }^{*}$ Crisis & $\begin{array}{c}0.0007 \\
(0.0015)\end{array}$ & $\begin{array}{c}0.0020 \\
(0.0018)\end{array}$ & $\begin{array}{c}0.0061 \\
(0.0070)\end{array}$ & $\begin{array}{c}0.0079 \\
(0.0052)\end{array}$ \\
\hline Other Cash flow ${ }_{\mathrm{t}} /$ Asset $_{\mathrm{t}-1} *$ No Crisis & $\begin{array}{c}0.0432 * * * \\
(0.0097)\end{array}$ & $\begin{array}{c}0.0285 * * * \\
(0.0049)\end{array}$ & $\begin{array}{c}0.0685^{* * * *} \\
(0.0182)\end{array}$ & $\begin{array}{c}0.0357 * * * \\
(0.0067)\end{array}$ \\
\hline Other Cash flow ${ }_{t} /$ Asset $_{t-1}{ }^{*}$ Crisis & $\begin{array}{c}0.0464 * * * \\
(0.0077)\end{array}$ & $\begin{array}{c}0.0174 * * * \\
(0.0049)\end{array}$ & $\begin{array}{c}0.0678 * * * \\
(0.0137) \\
\end{array}$ & $\begin{array}{c}0.0130^{*} \\
(0.0067) \\
\end{array}$ \\
\hline Group size*Industry*Year FE & \multicolumn{2}{|c|}{ Yes } & \multicolumn{2}{|c|}{ Yes } \\
\hline Group size*Location*Year FE & \multicolumn{2}{|c|}{ Yes } & \multicolumn{2}{|c|}{ Yes } \\
\hline Group*Year FE & \multicolumn{2}{|c|}{ No } & \multicolumn{2}{|c|}{ Yes } \\
\hline Firm FE & \multicolumn{2}{|c|}{ Yes } & \multicolumn{2}{|c|}{ Yes } \\
\hline Group*Year \& Firm Clustered St. Errors & \multicolumn{2}{|c|}{ Yes } & \multicolumn{2}{|c|}{ Yes } \\
\hline Observations & \multicolumn{2}{|c|}{170,810} & \multicolumn{2}{|c|}{109,552} \\
\hline R-squared & \multicolumn{2}{|c|}{0.793} & \multicolumn{2}{|c|}{0.864} \\
\hline
\end{tabular}




\section{Table 6A: Intra-Group Capital Transfers and Bank Health}

This table reports regressions of intra-group transfers as a function of sales growth and cash flow at the firm-level and cash flow and sales growth for other firms affiliated with the same group. Increases in the dependent variable reflect increased borrowing from group-affiliated sources.

\section{Dependent Variable $\quad$ Intra-Group Financial Position ${ }_{t} /$ Assets $_{t-1}$}

\begin{tabular}{|c|c|c|c|c|}
\hline \multirow[b]{3}{*}{ Own Fundamentals: } & \multicolumn{2}{|c|}{ All Years } & \multicolumn{2}{|c|}{ Post-Crisis Only } \\
\hline & (1) & (2) & (3) & (4) \\
\hline & & & & \\
\hline Sales growth & $\begin{array}{c}0.0060^{* * *} \\
(0.0019)\end{array}$ & $\begin{array}{c}0.0088^{* *} \\
(0.0039)\end{array}$ & $\begin{array}{c}0.0082^{* * *} \\
(0.0024)\end{array}$ & $\begin{array}{c}0.0129 * * * \\
(0.0050)\end{array}$ \\
\hline Sales growth ${ }_{\mathrm{t}}{ }^{\text {Bad loans }} \mathrm{t}_{\mathrm{t}-1}$ & $\begin{array}{c}-0.1206^{* *} \\
(0.0568)\end{array}$ & $\begin{array}{c}-0.1916^{*} \\
(0.1085)\end{array}$ & $\begin{array}{c}-0.1756^{* * *} \\
(0.0634)\end{array}$ & $\begin{array}{l}-0.2194 * \\
(0.1245)\end{array}$ \\
\hline Cash flow $_{t} /$ Asset $_{t-1}$ & $\begin{array}{c}-0.0064 \\
(0.0197)\end{array}$ & $\begin{array}{c}-0.0573 \\
(0.0356)\end{array}$ & $\begin{array}{c}0.0047 \\
(0.0235)\end{array}$ & $\begin{array}{c}-0.0490 \\
(0.0417)\end{array}$ \\
\hline Cash flow $_{\mathrm{t}} /$ Asset $_{\mathrm{t}-1} *$ Bad loans $_{\mathrm{t}-1}$ & $\begin{array}{c}-2.6131 * * * \\
(0.5096)\end{array}$ & $\begin{array}{c}-2.2147^{* *} \\
(0.8919)\end{array}$ & $\begin{array}{c}-2.6281 * * * \\
(0.5466)\end{array}$ & $\begin{array}{c}-2.0822 * * \\
(0.9748)\end{array}$ \\
\hline Bad loans ${ }_{t-1}$ & $\begin{array}{l}0.0948 * \\
(0.0571)\end{array}$ & $\begin{array}{c}0.1755^{*} \\
(0.1045)\end{array}$ & $\begin{array}{c}0.0840 \\
(0.0606)\end{array}$ & $\begin{array}{c}0.2167^{*} \\
(0.1181)\end{array}$ \\
\hline \multicolumn{5}{|l|}{ Other Fundamentals: } \\
\hline Other Sales growth ${ }_{t}$ & $\begin{array}{l}-0.0000 \\
(0.0020)\end{array}$ & $\begin{array}{c}0.0053 \\
(0.0065)\end{array}$ & $\begin{array}{l}-0.0007 \\
(0.0025)\end{array}$ & $\begin{array}{l}-0.0019 \\
(0.0075)\end{array}$ \\
\hline Other Sales growth ${ }_{\mathrm{t}}{ }^{\mathrm{B} a d}$ loans $_{\mathrm{t}-1}$ & $\begin{array}{l}-0.0007 \\
(0.0590)\end{array}$ & $\begin{array}{c}-0.1275 \\
(0.1692)\end{array}$ & $\begin{array}{c}0.0501 \\
(0.0663)\end{array}$ & $\begin{array}{c}0.2041 \\
(0.1858)\end{array}$ \\
\hline Other Cash flow ${ }_{t} /$ Asset $_{t-1}$ & $\begin{array}{c}0.0236 * * * \\
(0.0071)\end{array}$ & $\begin{array}{c}0.0258 * * \\
(0.0101)\end{array}$ & $\begin{array}{c}0.0230 * * \\
(0.0096)\end{array}$ & $\begin{array}{c}0.0286 * * \\
(0.0129)\end{array}$ \\
\hline Other Cash flow $_{\mathrm{t}}$ /Asset $_{\mathrm{t}-1} *$ Bad loans $_{\mathrm{t}-1}$ & $\begin{array}{c}0.1168 \\
(0.1855) \\
\end{array}$ & $\begin{array}{c}-0.0661 \\
(0.2443) \\
\end{array}$ & $\begin{array}{c}0.0751 \\
(0.2129) \\
\end{array}$ & $\begin{array}{c}-0.0316 \\
(0.2809) \\
\end{array}$ \\
\hline Industry*Year FE & Yes & Yes & Yes & Yes \\
\hline Location*Year FE & Yes & Yes & Yes & Yes \\
\hline Group*Year FE & No & Yes & No & Yes \\
\hline Firm FE & Yes & Yes & Yes & Yes \\
\hline Group*Year Clustered St. Errors & Yes & Yes & Yes & Yes \\
\hline Firm Clustered St. Errors & Yes & Yes & Yes & Yes \\
\hline Observations & 127,450 & 70,524 & 84,652 & 46,896 \\
\hline R-squared & 0.780 & 0.865 & 0.834 & 0.893 \\
\hline
\end{tabular}




\section{Table 6B: Intra-Group Capital Transfers and Bank Health}

This table reports regressions of intra-group transfers as a function of sales growth and cash flow at the firm-level and cash flow and sales growth for other firms affiliated with the same group. Columns 1 and 2 represent one regression, and columns 3 and 4 represent the other. Increases in the dependent variable reflect increased borrowing from group-affiliated sources.

\begin{tabular}{|c|c|c|c|c|}
\hline \multirow{4}{*}{ Dependent Variable } & \multicolumn{4}{|c|}{ Intra-Group Financial Position $_{\mathrm{t}} /$ Assets $_{\mathrm{t}-1}$} \\
\hline & $(1)$ & $(2)$ & (3) & $(4)$ \\
\hline & Small & Large & Small & Large \\
\hline & Groups & Groups & Groups & Groups \\
\hline \multicolumn{5}{|l|}{ Own Fundamentals: } \\
\hline Sales growth & $\begin{array}{c}0.0029 \\
(0.0024)\end{array}$ & $\begin{array}{c}0.0082 * * * \\
(0.0030)\end{array}$ & $\begin{array}{c}0.0007 \\
(0.0086)\end{array}$ & $\begin{array}{c}0.0104^{* *} \\
(0.0046)\end{array}$ \\
\hline Sales growth ${ }_{\mathrm{t}}$ Bad loans $_{\mathrm{t}-1}$ & $\begin{array}{c}-0.1091 \\
(0.0706)\end{array}$ & $\begin{array}{c}-0.1112 \\
(0.0903)\end{array}$ & $\begin{array}{c}-0.1637 \\
(0.2039)\end{array}$ & $\begin{array}{c}-0.1824 \\
(0.1343)\end{array}$ \\
\hline Cash flow $_{\mathrm{t}} /$ Asset $_{\mathrm{t}-1}$ & $\begin{array}{c}0.0851 * * * \\
(0.0299)\end{array}$ & $\begin{array}{l}-0.0460^{*} \\
(0.0252)\end{array}$ & $\begin{array}{c}0.0617 \\
(0.0794)\end{array}$ & $\begin{array}{c}-0.0915^{* *} \\
(0.0406)\end{array}$ \\
\hline Cash flow $_{\mathrm{t}} /$ Asset $_{\mathrm{t}-1} *$ Bad $_{\text {loans }} \mathrm{t}-1$ & $\begin{array}{c}-4.2366 * * * \\
(0.8152)\end{array}$ & $\begin{array}{c}-1.9996 * * * \\
(0.6437)\end{array}$ & $\begin{array}{l}-2.5242 \\
(2.0713)\end{array}$ & $\begin{array}{c}-2.0907 * * \\
(1.0217)\end{array}$ \\
\hline Bad loans $_{\mathrm{t}-1}$ & $\begin{array}{c}0.1876 * * \\
(0.0882)\end{array}$ & $\begin{array}{c}0.0706 \\
(0.0732)\end{array}$ & $\begin{array}{c}0.1813 \\
(0.2350)\end{array}$ & $\begin{array}{c}0.1950 \\
(0.1190)\end{array}$ \\
\hline \multicolumn{5}{|l|}{ Other Fundamentals: } \\
\hline Other Sales growth ${ }_{t}$ & $\begin{array}{c}-0.0022 \\
(0.0026)\end{array}$ & $\begin{array}{c}0.0009 \\
(0.0030)\end{array}$ & $\begin{array}{l}-0.0094 \\
(0.0117)\end{array}$ & $\begin{array}{c}0.0107 \\
(0.0088)\end{array}$ \\
\hline Other Sales growth ${ }_{\mathrm{t}}{ }^{\text {Bad } \text { loans }_{\mathrm{t}-1}}$ & $\begin{array}{c}0.0443 \\
(0.0771)\end{array}$ & $\begin{array}{l}-0.0141 \\
(0.0905)\end{array}$ & $\begin{array}{c}0.0869 \\
(0.2642)\end{array}$ & $\begin{array}{c}-0.2852 \\
(0.2317)\end{array}$ \\
\hline Other Cash flow ${ }_{t} /$ Asset $_{t-1}$ & $\begin{array}{c}0.0356 * * \\
(0.0157)\end{array}$ & $\begin{array}{c}0.0198 * * \\
(0.0078)\end{array}$ & $\begin{array}{l}0.0673 * \\
(0.0368)\end{array}$ & $\begin{array}{l}0.0211^{*} \\
(0.0108)\end{array}$ \\
\hline 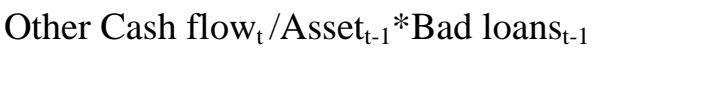 & $\begin{array}{l}-0.1050 \\
(0.4417) \\
\end{array}$ & $\begin{array}{c}0.1671 \\
(0.2042) \\
\end{array}$ & $\begin{array}{c}-0.7921 \\
(0.9149)\end{array}$ & $\begin{array}{c}-0.0098 \\
(0.2596)\end{array}$ \\
\hline Group size*Industry*Year FE & \multicolumn{2}{|c|}{ Yes } & \multicolumn{2}{|c|}{ Yes } \\
\hline Group size*Location*Year FE & \multicolumn{2}{|c|}{ Yes } & \multicolumn{2}{|c|}{ Yes } \\
\hline Group*Year FE & \multicolumn{2}{|c|}{ No } & \multicolumn{2}{|c|}{ Yes } \\
\hline Firm FE & \multicolumn{2}{|c|}{ Yes } & \multicolumn{2}{|c|}{ Yes } \\
\hline Group*Year Clustered St. Errors & \multicolumn{2}{|c|}{ Yes } & \multicolumn{2}{|c|}{ Yes } \\
\hline Firm Clustered St. Errors & \multicolumn{2}{|c|}{ Yes } & \multicolumn{2}{|c|}{ Yes } \\
\hline Observations & \multicolumn{2}{|c|}{127,094} & \multicolumn{2}{|c|}{69,572} \\
\hline R-squared & \multicolumn{2}{|c|}{0.787} & \multicolumn{2}{|c|}{0.872} \\
\hline
\end{tabular}




\section{Table 7: Intra-Group Capital Transfers and Bank Health with Above-Median Sales Indicator}

This table reports regressions of intra-group transfers as a function of sales growth and cash flow at the firm-level and cash flow and sales growth for other firms affiliated with the same group. Columns 1 and 2 represent one regression, and columns 3 and 4 represent the other. Increases in the dependent variable reflect increased borrowing from group-affiliated sources.

\begin{tabular}{|c|c|c|c|c|}
\hline \multirow[t]{4}{*}{ Dependent Variable } & \multicolumn{4}{|c|}{ Intra-Group Financial Position $/$ Assets $_{\mathrm{t}-1}$} \\
\hline & $(1)$ & $(2)$ & (3) & $(4)$ \\
\hline & Small & Large & Small & Large \\
\hline & Groups & Groups & Groups & Groups \\
\hline \multicolumn{5}{|l|}{ Own Fundamentals: } \\
\hline Sales growth & $\begin{array}{c}0.0016 \\
(0.0025)\end{array}$ & $\begin{array}{l}0.0055^{*} \\
(0.0031)\end{array}$ & $\begin{array}{c}-0.0013 \\
(0.0088)\end{array}$ & $\begin{array}{c}0.0068 \\
(0.0048)\end{array}$ \\
\hline \multirow[t]{2}{*}{ Sales growth ${ }_{t} *$ Bad loans $\mathrm{t}_{\mathrm{t}-1}$} & -0.1088 & -0.1200 & -0.1716 & -0.1987 \\
\hline & $(0.0706)$ & $(0.0903)$ & $(0.2039)$ & $(0.1343)$ \\
\hline \multirow[t]{2}{*}{ Cash flow $_{t} /$ Asset $_{t-1}$} & $0.0738 * *$ & -0.0337 & 0.0690 & -0.0582 \\
\hline & $(0.0317)$ & $(0.0264)$ & $(0.0849)$ & $(0.0435)$ \\
\hline \multirow[t]{2}{*}{ Cash flow $_{\mathrm{t}} /$ Asset $_{\mathrm{t}-1} *$ Bad loans $_{\mathrm{t}-1}$} & $-4.2223 * * *$ & $-2.0389 * * *$ & -2.4880 & $-2.1756 * *$ \\
\hline & $(0.8129)$ & $(0.6434)$ & $(2.0727)$ & $(1.0231)$ \\
\hline \multirow[t]{2}{*}{ Bad loans $_{\mathrm{t}-1}$} & $0.1891 * *$ & 0.0717 & 0.1900 & $0.1968 *$ \\
\hline & $(0.0881)$ & $(0.0731)$ & $(0.2349)$ & $(0.1189)$ \\
\hline \multicolumn{5}{|l|}{ Other Fundamentals: } \\
\hline Other Sales growth $\mathrm{t}_{\mathrm{t}}$ & $\begin{array}{l}-0.0023 \\
(0.0026)\end{array}$ & $\begin{array}{c}0.0009 \\
(0.0030)\end{array}$ & $\begin{array}{l}-0.0090 \\
(0.0117)\end{array}$ & $\begin{array}{c}0.0101 \\
(0.0088)\end{array}$ \\
\hline \multirow[t]{2}{*}{ Other Sales growth ${ }_{\mathrm{t}}{ }^{\text {Bad } \text { loans }_{\mathrm{t}-1}}$} & 0.0448 & -0.0178 & 0.0871 & -0.2826 \\
\hline & $(0.0771)$ & $(0.0904)$ & $(0.2636)$ & $(0.2314)$ \\
\hline \multirow[t]{2}{*}{ Other Cash flow ${ }_{t} /$ Asset $_{\text {t-1 }}$} & 0.0224 & $0.0139 *$ & $0.0621 *$ & 0.0127 \\
\hline & $(0.0163)$ & $(0.0084)$ & $(0.0374)$ & $(0.0114)$ \\
\hline \multirow[t]{2}{*}{ Other Cash flow ${ }_{\mathrm{t}} /$ Asset $_{\mathrm{t}-1} *$ Bad loans $\mathrm{t}_{\mathrm{t}-1}$} & -0.0820 & 0.1889 & -0.8173 & 0.0237 \\
\hline & $(0.4361)$ & $(0.2046)$ & $(0.9094)$ & $(0.2593)$ \\
\hline \multicolumn{5}{|l|}{ Cash Flow Interactions: } \\
\hline \multirow[t]{2}{*}{ Above-Median Sales Growth } & 0.0012 & $0.0040^{* * *}$ & 0.0043 & $0.0055 * *$ \\
\hline & $(0.0017)$ & $(0.0014)$ & $(0.0047)$ & $(0.0024)$ \\
\hline \multirow{2}{*}{ Above-Median Sales*Cash flow ${ }_{t} /$ Assets $_{\mathrm{t}-1}$} & 0.0167 & $-0.0316^{*}$ & -0.0273 & $-0.0745^{* * *}$ \\
\hline & $(0.0217)$ & $(0.0178)$ & $(0.0626)$ & $(0.0278)$ \\
\hline \multirow{2}{*}{ Above-Median Sales*Other Cash flow ${ }_{\mathrm{t}} /$ Assets $_{\mathrm{t}-1}$} & $0.0247 * *$ & $0.0101 * *$ & 0.0126 & $0.0141^{* *}$ \\
\hline & $(0.0113)$ & $(0.0047)$ & $(0.0207)$ & $(0.0059)$ \\
\hline Group size*Industry*Year FE & \multicolumn{2}{|c|}{ Yes } & \multicolumn{2}{|c|}{ Yes } \\
\hline Group size*Location*Year FE & \multicolumn{2}{|c|}{ Yes } & \multicolumn{2}{|c|}{ Yes } \\
\hline Group*Year FE & \multicolumn{2}{|c|}{ No } & \multicolumn{2}{|c|}{ Yes } \\
\hline Firm FE & \multicolumn{2}{|c|}{ Yes } & \multicolumn{2}{|c|}{ Yes } \\
\hline Group*Year Clustered St. Errors & \multicolumn{2}{|c|}{ Yes } & \multicolumn{2}{|c|}{ Yes } \\
\hline Firm Clustered St. Errors & \multicolumn{2}{|c|}{ Yes } & & \\
\hline Observations & 127 & & & \\
\hline R-squared & & & & \\
\hline
\end{tabular}




\section{Table 8: Intra-Group Capital Transfers and Bank Borrowing}

This table reports regressions of intra-group transfers as a function of sales growth, cash flow and rating at the firm-level and cash flow, sales growth and rating for other firms affiliated with the same group. Columns 1 and 2 include just net financial transfers, while columns 3 and 4 incorporate net trade position. Increases in the dependent variable reflect increased borrowing from group-affiliated sources.

\begin{tabular}{|c|c|c|c|c|c|c|}
\hline & \\
\hline & (1) & (2) & (3) & (4) & (5) & (6) \\
\hline Own Fundamentals: & Pooled & Pooled & $\begin{array}{c}\text { Small } \\
\text { Groups }\end{array}$ & $\begin{array}{l}\text { Large } \\
\text { Groups }\end{array}$ & $\begin{array}{c}\text { Small } \\
\text { Groups }\end{array}$ & $\begin{array}{l}\text { Large } \\
\text { Groups }\end{array}$ \\
\hline Sales growth $_{\mathrm{t}} *$ No Crisis & $\begin{array}{c}0.0081^{* * * *} \\
(0.0018)\end{array}$ & $\begin{array}{c}0.0053 \\
(0.0035)\end{array}$ & $\begin{array}{c}-0.0026 \\
(0.0025)\end{array}$ & $\begin{array}{c}0.0134^{* * *} \\
(0.0024)\end{array}$ & $\begin{array}{c}-0.0312^{* *} \\
(0.0143)\end{array}$ & $\begin{array}{c}0.0077 * * \\
(0.0037)\end{array}$ \\
\hline Sales growth $_{\mathrm{t}}{ }^{*}$ Crisis & $\begin{array}{c}0.0071^{* * *} \\
(0.0011)\end{array}$ & $\begin{array}{c}0.0124 * * * \\
(0.0023)\end{array}$ & $\begin{array}{c}0.0046 * * * \\
(0.0014)\end{array}$ & $\begin{array}{c}0.0089 * * * \\
(0.0017)\end{array}$ & $\begin{array}{c}0.0142^{* * *} \\
(0.0049)\end{array}$ & $\begin{array}{c}0.0130^{* * *} \\
(0.0026)\end{array}$ \\
\hline Cash flow $_{\mathrm{t}} /$ Asset $_{\mathrm{t}-1} *$ No Crisis & $\begin{array}{c}-0.0216 \\
(0.0191)\end{array}$ & $\begin{array}{c}-0.0540 * \\
(0.0310)\end{array}$ & $\begin{array}{c}0.0529 \\
(0.0333)\end{array}$ & $\begin{array}{c}-0.0462 * * \\
(0.0226)\end{array}$ & $\begin{array}{c}0.0747 \\
(0.0922)\end{array}$ & $\begin{array}{c}-0.0743^{* *} \\
(0.0335)\end{array}$ \\
\hline Cash flow $_{t} /$ Asset $_{\mathrm{t}-1} *$ Crisis & $\begin{array}{c}-0.1592 * * * \\
(0.0132)\end{array}$ & $\begin{array}{c}-0.2222 * * * \\
(0.0211)\end{array}$ & $\begin{array}{c}-0.0883 * * * \\
(0.0192)\end{array}$ & $\begin{array}{c}-0.1905^{* * *} \\
(0.0168)\end{array}$ & $\begin{array}{c}-0.1203^{* * *} \\
(0.0403)\end{array}$ & $\begin{array}{c}-0.2392 * * * \\
(0.0243)\end{array}$ \\
\hline Bank debt ${ }_{t-1} /$ Asset $_{\mathrm{t}-1} *$ No Crisis & $\begin{array}{c}-0.0607^{* * *} \\
(0.0062)\end{array}$ & $\begin{array}{c}-0.0802 * * * \\
(0.0103)\end{array}$ & $\begin{array}{c}-0.0462^{* * *} \\
(0.0089)\end{array}$ & $\begin{array}{c}-0.0684^{* * *} \\
(0.0075)\end{array}$ & $\begin{array}{c}-0.0638^{* * *} \\
(0.0219)\end{array}$ & $\begin{array}{c}-0.0817^{* * *} \\
(0.0115)\end{array}$ \\
\hline Bank debt ${ }_{\mathrm{t}-1} /$ Asset $_{\mathrm{t}-1} *$ Crisis & $\begin{array}{c}-0.0195 * * * \\
(0.0062)\end{array}$ & $\begin{array}{c}-0.0364 * * * \\
(0.0099)\end{array}$ & $\begin{array}{c}-0.0114 \\
(0.0084)\end{array}$ & $\begin{array}{c}-0.0262 * * * \\
(0.0074)\end{array}$ & $\begin{array}{c}-0.0470^{* *} \\
(0.0189)\end{array}$ & $\begin{array}{c}-0.0315^{* * *} \\
(0.0112)\end{array}$ \\
\hline \multicolumn{7}{|l|}{ Other Fundamentals: } \\
\hline Other Sales growth ${ }_{\mathrm{t}}^{*}$ No Crisis & $\begin{array}{c}0.0006 \\
(0.0019)\end{array}$ & $\begin{array}{c}-0.0029 \\
(0.0065)\end{array}$ & $\begin{array}{c}0.0001 \\
(0.0028)\end{array}$ & $\begin{array}{c}-0.0006 \\
(0.0026)\end{array}$ & $\begin{array}{c}-0.0535 * * * \\
(0.0203)\end{array}$ & $\begin{array}{c}-0.0039 \\
(0.0078)\end{array}$ \\
\hline Other Sales growth ${ }_{t}{ }^{*}$ Crisis & $\begin{array}{c}0.0018 \\
(0.0013)\end{array}$ & $\begin{array}{c}0.0115^{* * *} \\
(0.0043)\end{array}$ & $\begin{array}{c}0.0005 \\
(0.0017)\end{array}$ & $\begin{array}{c}0.0030 \\
(0.0020)\end{array}$ & $\begin{array}{c}0.0188 * * \\
(0.0077)\end{array}$ & $\begin{array}{c}0.0102 * \\
(0.0055)\end{array}$ \\
\hline Other Cash flow $/$ Asset $_{\mathrm{t}-1} *$ No Crisis & $\begin{array}{c}0.0228^{* * *} \\
(0.0047)\end{array}$ & $\begin{array}{c}0.0256^{* * *} \\
(0.0070)\end{array}$ & $\begin{array}{c}0.0273^{* * *} \\
(0.0104)\end{array}$ & $\begin{array}{c}0.0192^{* * *} \\
(0.0052)\end{array}$ & $\begin{array}{c}0.0532 * \\
(0.0273)\end{array}$ & $\begin{array}{c}0.0239 * * * \\
(0.0075)\end{array}$ \\
\hline Other Cash flow ${ }_{t} /$ Asset $_{\mathrm{t}-1} *$ Crisis & $\begin{array}{c}0.0172^{* * *} \\
(0.0046)\end{array}$ & $\begin{array}{c}0.0084 \\
(0.0069)\end{array}$ & $\begin{array}{c}0.0391^{* * *} \\
(0.0083)\end{array}$ & $\begin{array}{c}0.0120^{* *} \\
(0.0052)\end{array}$ & $\begin{array}{c}0.0269 \\
(0.0171)\end{array}$ & $\begin{array}{c}0.0086 \\
(0.0075)\end{array}$ \\
\hline Other Bank debt $t_{\mathrm{t}-1} /$ Asset $_{\mathrm{t}-1} *$ No Crisis & $\begin{array}{c}0.0054^{* * *} \\
(0.0008)\end{array}$ & $\begin{array}{c}0.0059^{* * *} \\
(0.0011)\end{array}$ & $\begin{array}{c}0.0072^{* * *} \\
(0.0015)\end{array}$ & $\begin{array}{c}0.0049 * * * \\
(0.0009)\end{array}$ & $\begin{array}{c}0.0101^{* * *} \\
(0.0024)\end{array}$ & $\begin{array}{c}0.0050^{* * *} \\
(0.0012)\end{array}$ \\
\hline Other Bank debt ${ }_{t-1} /$ Asset $_{\mathrm{t}-1} *$ Crisis & $\begin{array}{c}0.0048 * * * \\
(0.0008)\end{array}$ & $\begin{array}{c}0.0042^{* * *} \\
(0.0011)\end{array}$ & $\begin{array}{c}0.0076 * * * \\
(0.0014)\end{array}$ & $\begin{array}{c}0.0041^{* * *} \\
(0.0009)\end{array}$ & $\begin{array}{c}0.0117^{* * *} \\
(0.0023)\end{array}$ & $\begin{array}{c}0.0030 * * \\
(0.0012)\end{array}$ \\
\hline Industry*Year FE & Yes & Yes & \multicolumn{2}{|c|}{ Yes } & \multicolumn{2}{|c|}{ Yes } \\
\hline Location*Year FE & Yes & Yes & \multicolumn{2}{|c|}{ Yes } & \multicolumn{2}{|c|}{ Yes } \\
\hline Group*Year FE & No & Yes & \multicolumn{2}{|c|}{ No } & \multicolumn{2}{|c|}{ Yes } \\
\hline Firm FE & Yes & Yes & \multicolumn{2}{|c|}{ Yes } & \multicolumn{2}{|c|}{ Yes } \\
\hline Group*Year \& Firm Clustered St. Errors & Yes & Yes & \multicolumn{2}{|c|}{ Yes } & \multicolumn{2}{|c|}{ Yes } \\
\hline Observations & 146,225 & 96,140 & \multicolumn{2}{|c|}{145,872} & \multicolumn{2}{|c|}{95,304} \\
\hline R-squared & 0.787 & 0.854 & \multicolumn{2}{|c|}{0.793} & \multicolumn{2}{|c|}{0.860} \\
\hline
\end{tabular}




\section{Table 9: Intra-Group Capital Transfers and Bank Borrowing}

This table reports regressions of intra-group transfers as a function of sales growth, cash flow and rating at the firm-level and cash flow, sales growth and rating for other firms affiliated with the same group. Columns 1 and 2 represent one regression, and columns 3 and 4 represent the other. Increases in the dependent variable reflect increased borrowing from group-affiliated sources.

\section{Dependent Variable $\quad$ Intra-Group Financial Position ${ }_{t} /$ sssets $_{\mathrm{t}-1}$}

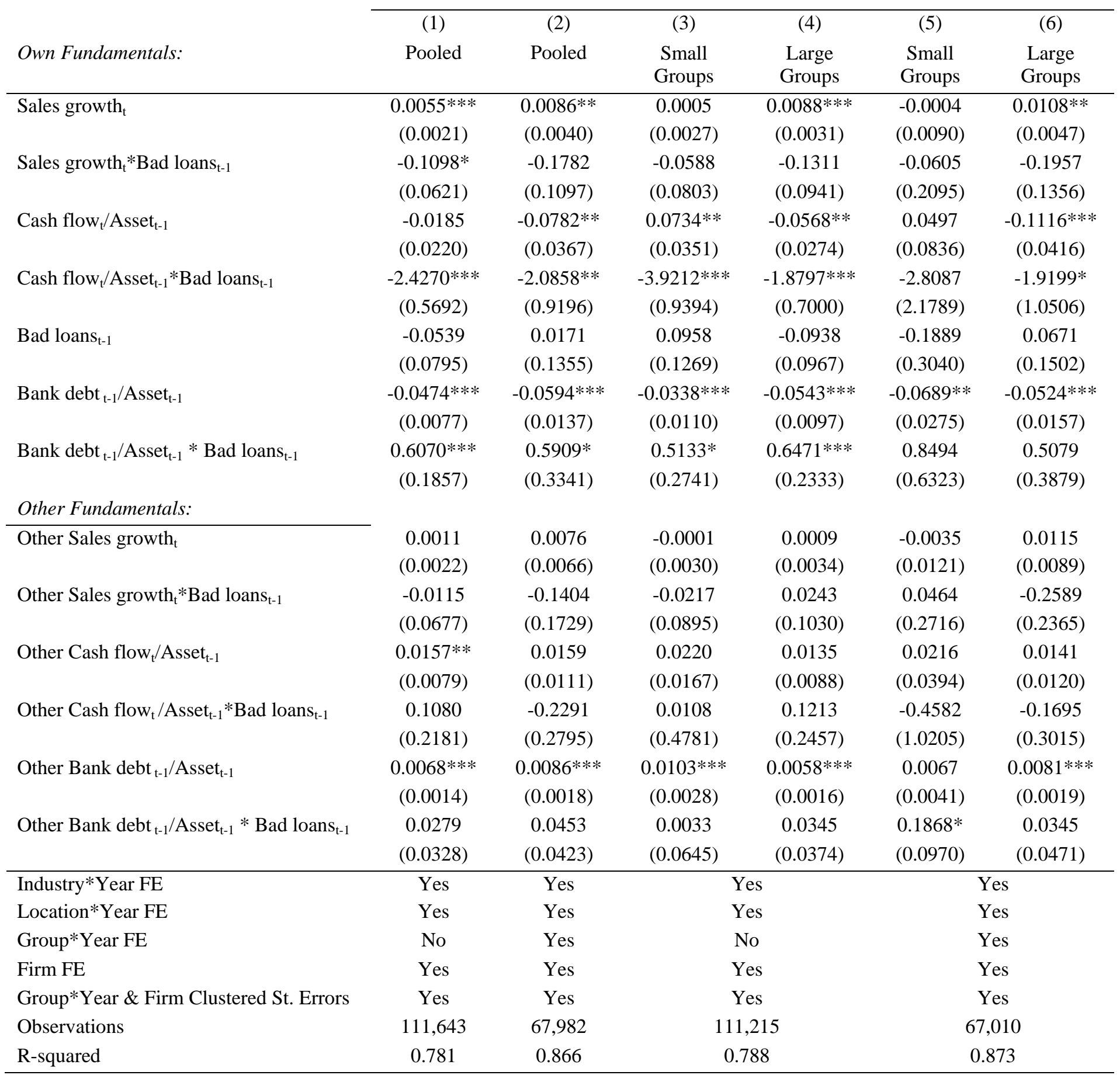




\section{Figure 1: Italian GDP growth rate and Aggregate Bad loans Ratio}

This figure reports Italian GDP growth rate and the aggregate bad loan to total loan ratio for the Italian banking system from 2003 to 2015.

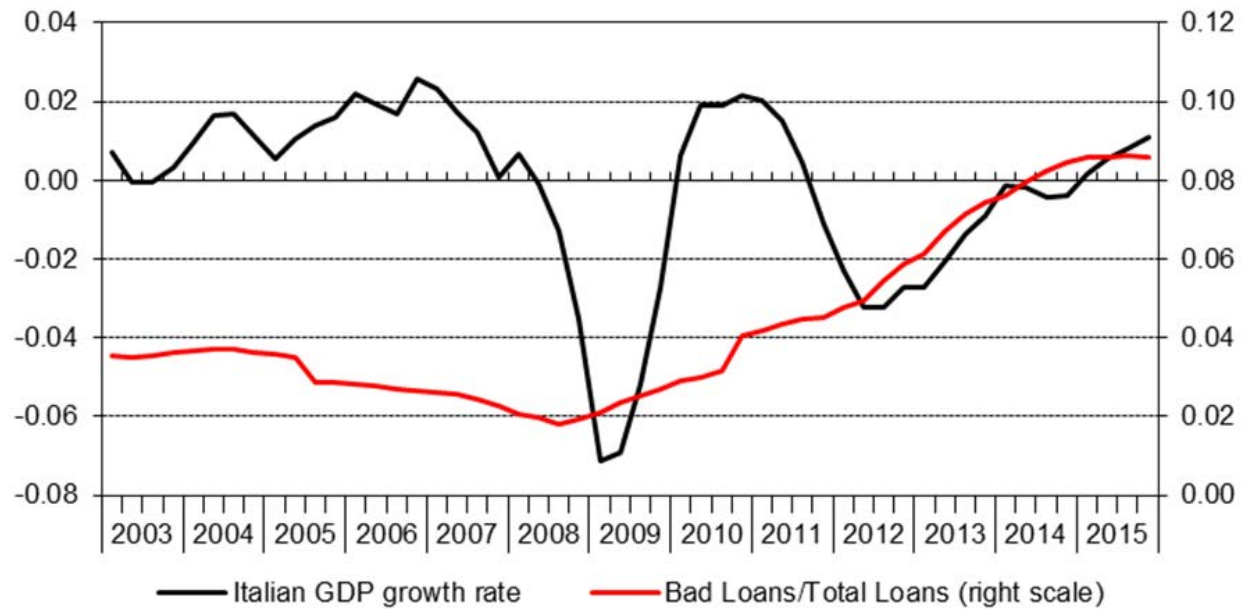

Figure 2: Gross Intra-Group Financial Debt

This figure reports the growth in aggregate Gross Intra-Group Financial Debt, bank debt for continuing firms. Values in 2004 normalized to 100. The description of variables and their data sources are provided in the Appendix.

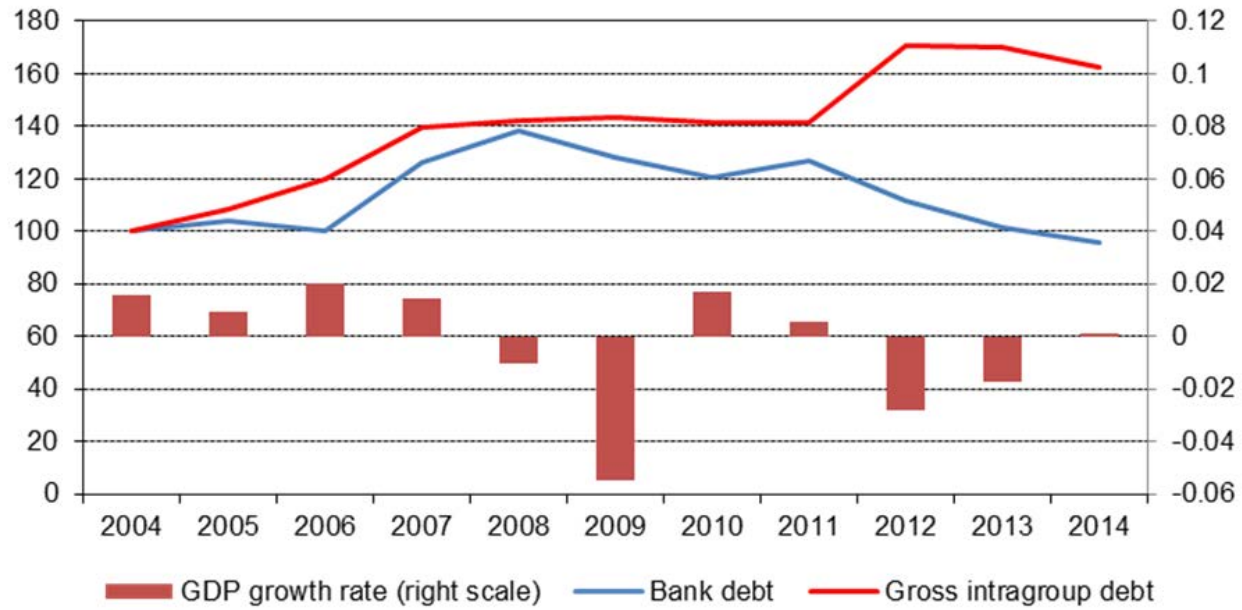




\section{Figure 3: Bad loans ratio}

This figure reports the time-series and cross-sectional variation of the median and $5^{\text {th }}$ and $95^{\text {th }}$ percentile range for the firm-bank’s bad loans-to-assets ratio, from 2004 to 2014. The description of variables and their data sources are provided in the Appendix.

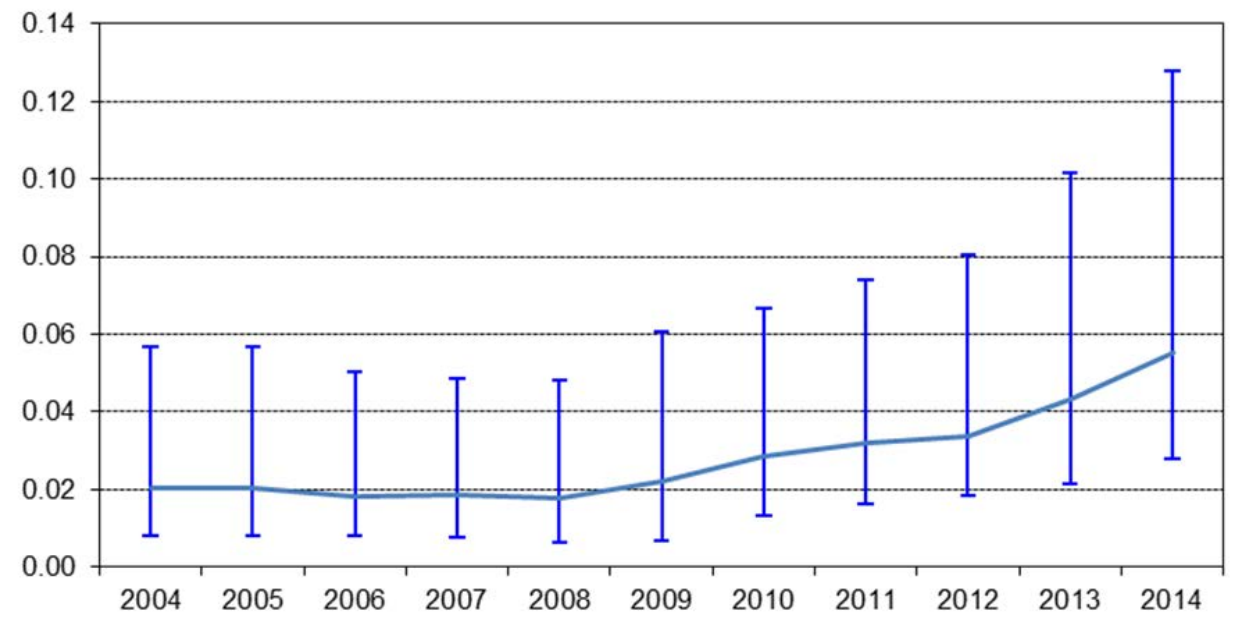

Figure 4: Kaplan-Meier survival estimates

This figure plots the Kaplan-Meier survival estimates for firms that exist in 2006 over the subsequent seven years (until 2013). The vertical axis equals the fraction of firms that remain in the sample in that year.

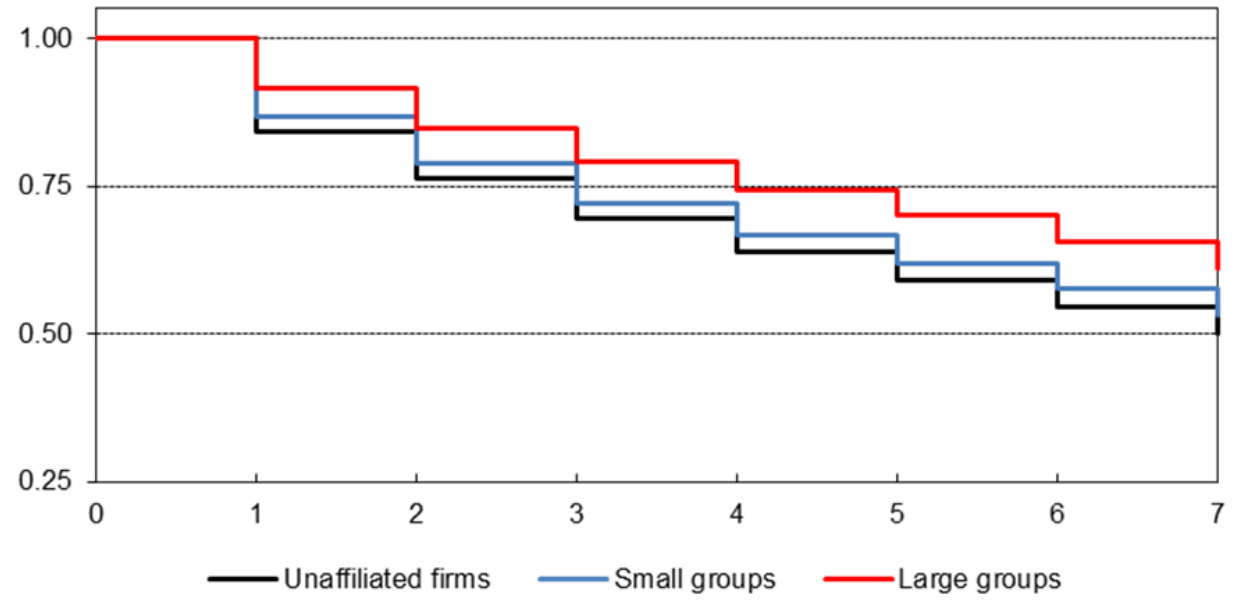




\section{Figure 5: Cash flow coefficients by year}

This figure reports the coefficient on firm cash flow in regressions of Net Intra-group Capital Transfers like those of Table 5, allowing the marginal effect to vary in each year in the sample.

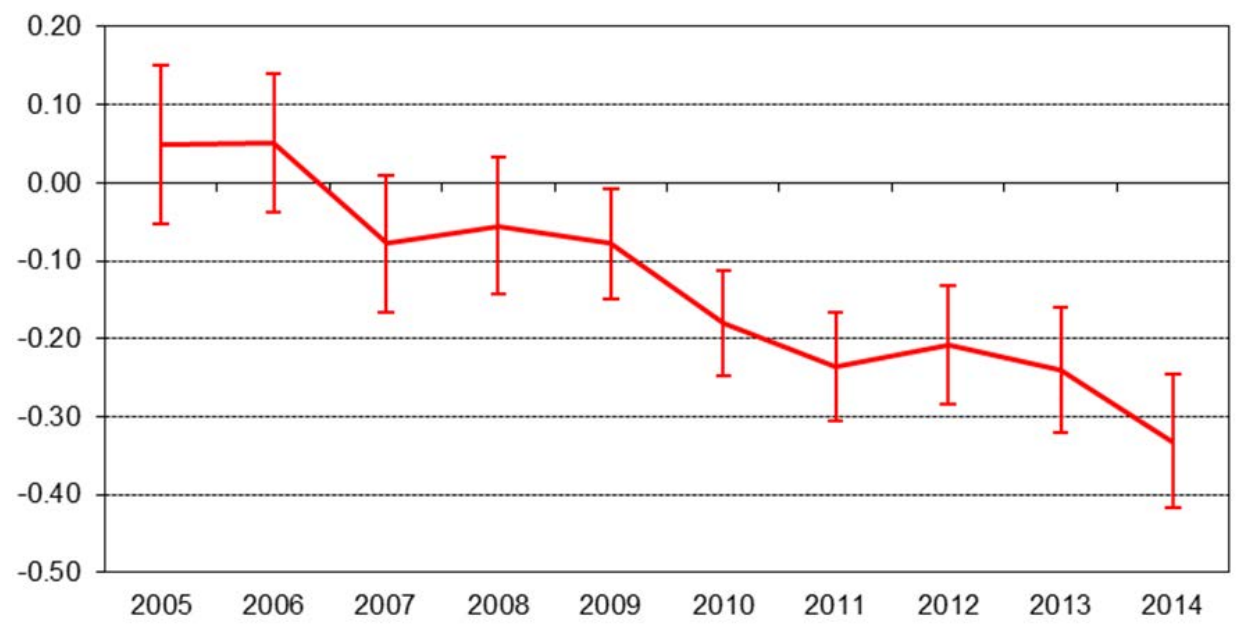

Figure 6: Marginal effect of own cash flow

This figure plots the marginal effect of own cash flow on intra group transfer (vertical axis) as a function of the bad loans ratio (horizontal axis), based on the models of Table 6A.

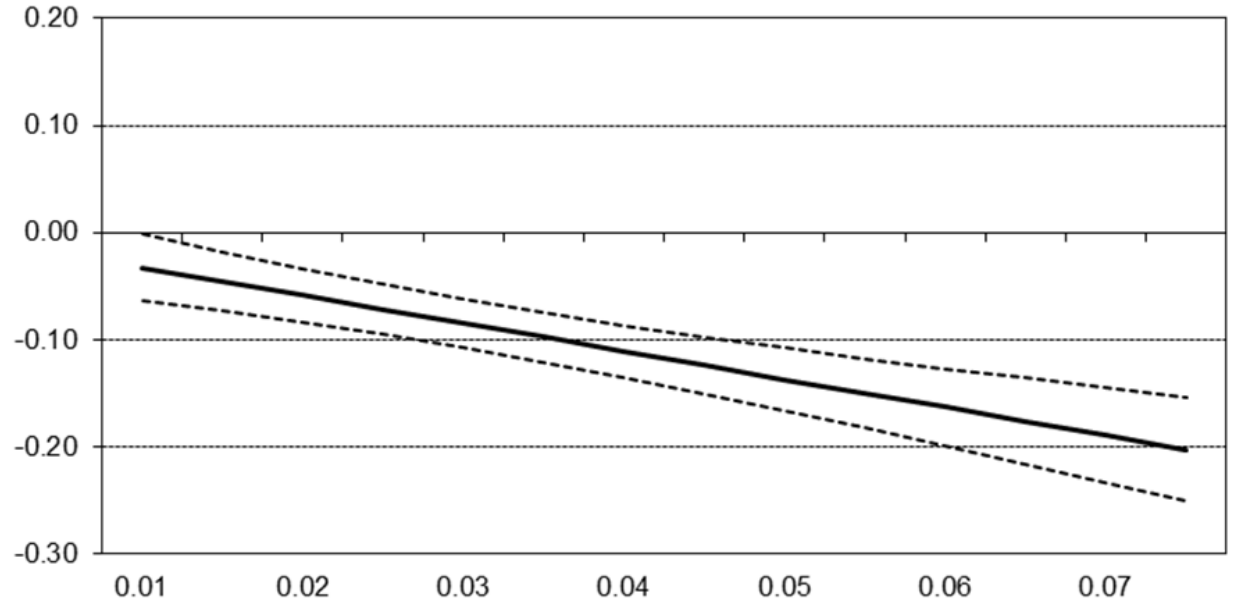


Figure 7: Marginal effect of own cash flow, by group size

This figure plots the marginal effect of own cash flow on intra group transfer (vertical axis) as a function of the bad loans ratio (horizontal axis), for small and large groups. The regression coefficients are based on the models of Table 6B.
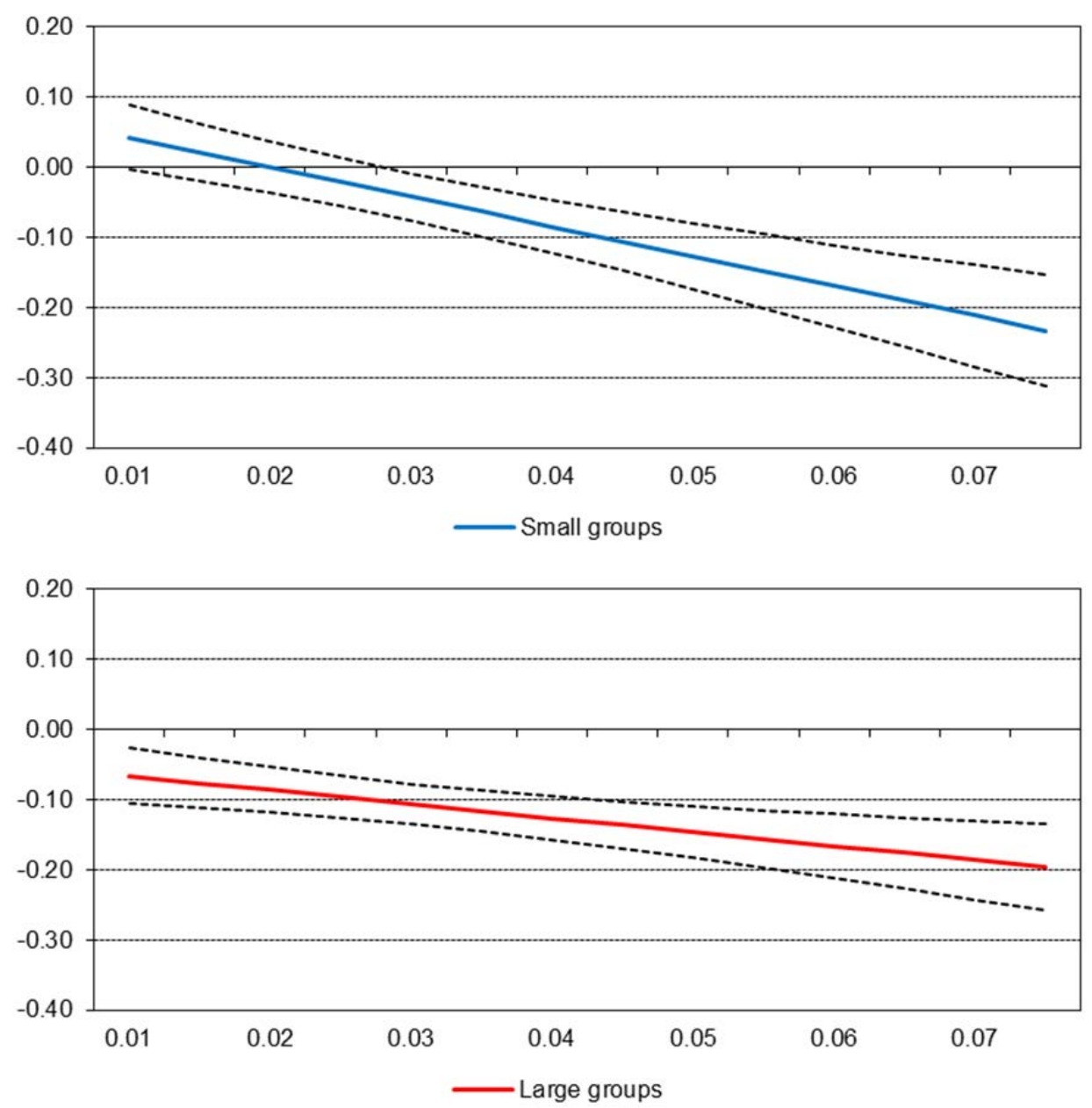